\title{
Synthesis, antibacterial action, and ribosome inhibition of deoxyspectinomycins
}

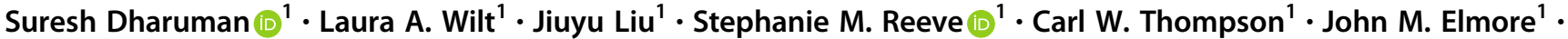 \\ Dimitri Shcherbakov ${ }^{2} \cdot$ Robin B. Lee $^{1} \cdot$ Erik C. Böttger $^{2} \cdot{\text { Richard E. Lee } \mathbb{B}^{1}}^{1}$
}

Received: 12 September 2020 / Revised: 13 December 2020 / Accepted: 3 January 2021 / Published online: 27 January 2021

(c) The Author(s) 2021. This article is published with open access

\begin{abstract}
Spectinomycin, an aminocyclitol antibiotic, is subject to inactivation by aminoglycoside modifying enzymes (AMEs) through adenylylation or phosphorylation of the 6-hydroxy group position. In this study, the effects of deoxygenation of the 2- and 6-hydroxy group positions on the spectinomycin actinamine ring are probed to evaluate their relationship to ribosomal binding and the antimicrobial activities of spectinomycin, semisynthetic aminomethyl spectinomycins (amSPCs), and spectinamides. To generate these analogs, an improved synthesis of 6-deoxyspectinomycin was developed using the Barton deoxygenation reaction. 6-Dehydrospectinamide was also synthesized from spectinamide $\mathbf{4}$ to evaluate the H-bond acceptor character on the C-6 position. All the synthesized analogs were tested for antibacterial activity against a panel of Gram $(+)$ and Gram (-) pathogens, plus Mycobacterium tuberculosis. The molecular contribution of the 2- and 6-hydroxy group and the aryl functionalities of all analogs were examined by measuring inhibition of ribosomal translation and molecular dynamics experiments with MM/GBSA analysis. The results of this work indicate that the 6-hydroxy group, which is the primary target of AMEs, is a required motif for antimicrobial activity in current analogs. Removal of the 6-hydroxy group could be partially rescued by offsetting ribosomal binding contributions made by the aryl side chains found in the spectinamide and amSPCs. This study builds on the knowledge of the structure-activity relationships of spectinomycin analogs and is being used to aid the design of next-generation spectinomycins.
\end{abstract}

\section{Introduction}

Spectinomycin, an aminoinositol antibiotic [1, 2], is an inhibitor of bacterial protein synthesis $\left(\mathrm{IC}_{50}=0.4 \mu \mathrm{g} \mathrm{ml}^{-1}\right.$ ) with moderate broad-spectrum activity against both Gram $(+)$ and Gram (-) bacteria (Fig. 1a). Spectinomycin binds to the interface between the minor groove of helix-34 of the $16 \mathrm{~S}$ ribosomal RNA and the RpsE protein to inhibit protein translation [3]. Clinically, spectinomycin has been widely

Supplementary information The online version of this article (https:// doi.org/10.1038/s41429-021-00408-3) contains supplementary material, which is available to authorized users.

Richard E. Lee

Richard.Lee@stjude.org

1 Department of Chemical Biology and Therapeutics, St. Jude Children's Research Hospital, Memphis, TN, USA

2 Institut für Medizinische Mikrobiologie, Universität Zürich, Zürich, Switzerland used to treat Neisseria gonorrheal infections [4] and is well tolerated at a high dosage, lacking the ototoxicity commonly associated with aminoglycoside antibiotics [5]. However, spectinomycin is subject to native efflux [6,7], target modification [8], and enzymatic inactivation of the drug $[8,9]$. Therefore, to overcome innate resistance mechanisms, we developed semisynthetic analogs of spectinomycin called spectinamides [10] and aminomethyl spectinomycins (amSPCs) [11]. The spectinamides have excellent narrow spectrum antitubercular activity, and the amSPCs have broad-spectrum activity against the common respiratory tract, sexually transmitted and biothreat bacterial pathogens (Fig. 1b, c) [12-14]. These analogs have improved bacterial accumulation, with the spectinamides overcoming efflux by the Rv1258c transporter found in Mycobacterium tuberculosis which transports spectinomycin [10]. While these analogs overcome the resistance from efflux pumps, they are still subject to modification by aminoglycoside modifying enzymes (AMEs) in nonmycobacterial pathogens, which limits their development for broader indications, particularly for the treatment of 


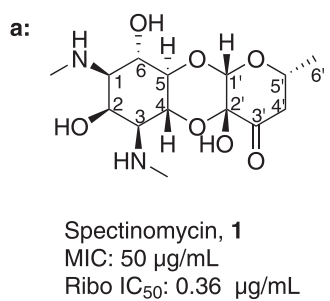

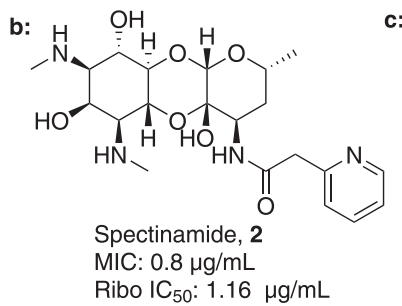

c:

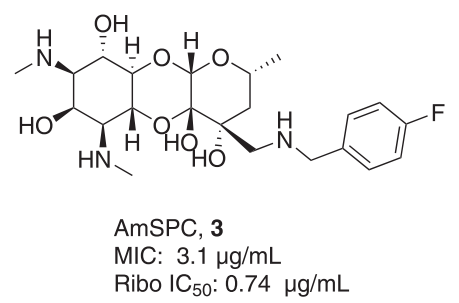

Fig. 1 a Structure of spectinomycin (1) with activity against M. tuberculosis and ribosomal $\mathrm{IC}_{50}$ against $M$. smegmatis ribosomes. b Structure of spectinamide $\mathbf{2}$ with activity against M. tuberculosis and ribosomal $\mathrm{IC}_{50}$ against $M$. smegmatis ribosomes. $\mathbf{c}$ Structure of amSPC 3 with activity against $S$. pneumoniae and ribosomal $\mathrm{IC}_{50}$ against M. smegmatis ribosomes<smiles>CNC1[C@@H]2O[C@]3(O)C(=O)C[C@@H](C)O[C@H]3O[C@@H]2C[C@H](NC)[C@H]1O</smiles>

6-Deoxyspectinomycin, 5

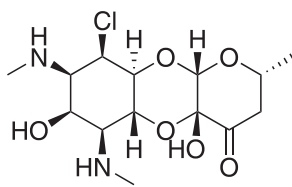

6-epichlorospectinomycin, 8<smiles>CN[C@H]1C[C@H]2O[C@H]3O[C@@H](C)C[C@H](NC(=O)Cc4ccccn4)[C@]3(O)O[C@]2(C)[C@H](NC)[C@@H]1O</smiles>

6-Deoxyspectinamide, 6

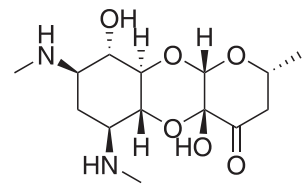

2-Deoxyspectinomycin, 9<smiles>CNC1C[C@H]2O[C@@H]3O[C@H](C)C[C@@](O)(CNCc4ccc(F)cc4)[C@]3(O)O[C@]2(C)C(NC)[C@@H]1O</smiles>

6-DeoxyamSpec, 7

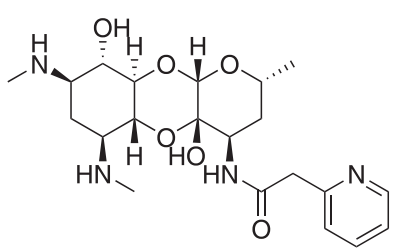

2-Deoxyspectinamide, 10

Fig. 2 Proposed analogs of deoxyspectinomycins to overcome aminoglycoside modifying enzyme resistance

Gram-negative infections $[15,16]$. One strategy to alleviate AME resistance is to remove the sites of inactivation found on aminoglycosides [17]. Spectinomycin is susceptible to inactivation by nucleotidyltransferases $\operatorname{ANT}(9)$ [18] and the bifunctional enzyme ANT $(3,9)$, as well as phosphorylation by the APH(9) enzyme, which all modify the 6-hydroxy group position of spectinomycin [15, 16, 19]. Previously, several deoxyspectinomycins were synthesized by researchers at Hoffmann-La Roche Inc. and were found to be microbiologically inactive [20-22]. However, it was unknown if the inactivity is due to lack of ribosomal binding or poor accumulation. As part of our systematic approach to develop the structure-activity relationship (SAR) around the spectinomycin ring, we chose to reinvestigate the antimicrobial properties of deoxyspectinomycin analogs and to evaluate their ability to inhibit bacterial ribosomes, which has not been previously reported.

In this study, we examine whether modifications to the 2- and 6-hydroxy groups in spectinomycin, spectinamides, and amSPCs (Fig. 2) can be tolerated, how modification or removal of these groups affects antibacterial potency, ribosome inhibition, and cellular accumulation, and finally, computationally examine the relative binding contributions of these motifs in the ribosome binding site. We report an improved synthesis of 6-deoxyspectinomycin using Barton's radical deoxygenation reaction as the key step [23] and demonstrate an efficient synthesis of 6- and 2-deoxyspectinamides and 6-deoxyaminomethyl spectinomycin (6-deoxy-amSPC) analogs [21]. 6-epi-chlorospectinomycins and 6dehydrospectinamide were also synthesized to examine hydrogen bonding acceptor character to the ribosome (Fig. 3). The antimicrobial activity and cellular accumulation of the analogs were determined, and the energetic contribution of key binding interactions was examined computationally. Results from these studies are combined to provide a holistic picture of the value of the 2- and 6hydroxy groups to spectinomycin binding and antimicrobial activity.

\section{Material and methods}

\section{Chemicals, reagents, and instrumental}

Spectinomycin dihydrochloride pentahydrate was purchased from Waterstone Technology (catalog number 81249, CAS number $22189-32-8,95 \%$ in purity). All solvents used for chromatography and liquid chromatography were purchased from Aldrich. Flash column chromatography silica 
Fig. 3 Proposed mechanism for 6-dehydrospectinamide $\mathbf{1 1}$ to sustain resistance from AMEs

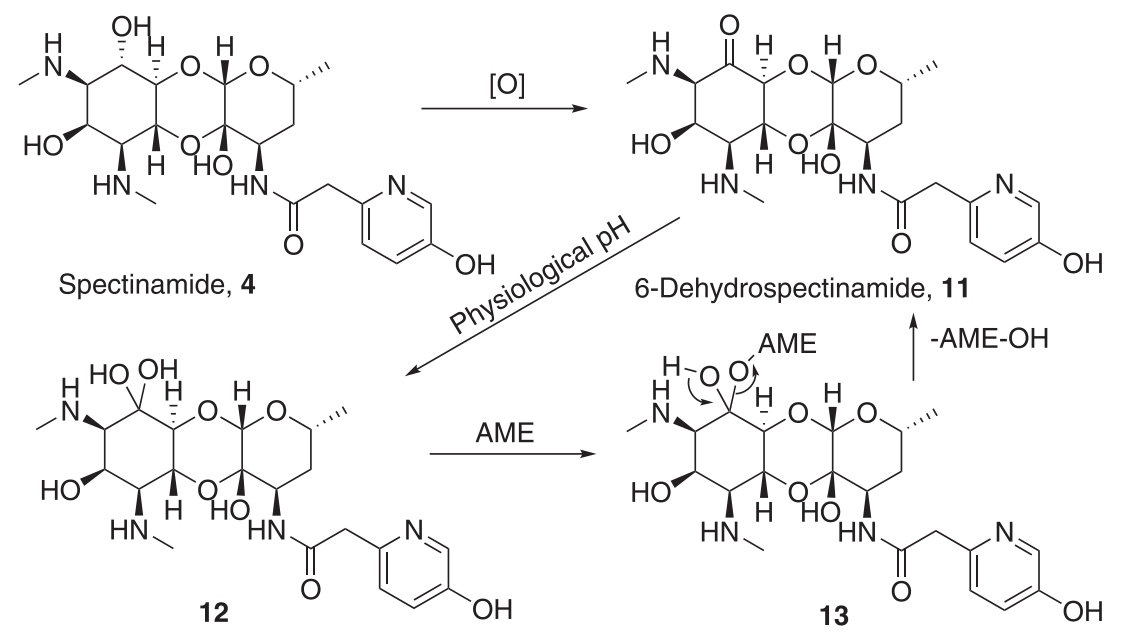

cartridges were obtained from Biotage Inc. Reactions were monitored by thin-layer chromatography on pre-coated Merch 60 F254 silica gel plates and visualized using UV light $(254 \mathrm{~nm})$. IR (neat) spectra were obtained using a Nicolet-iS5 FT-IR instrument. A Biotage FLASH column chromatography system was used to purify mixtures. ${ }^{1} \mathrm{H}$ NMR spectra were recorded on a Varian INOVA-500 spectrometer or on a Bruker $400 \mathrm{MHz}$ NMR spectrometer. Chemical shifts $(\delta)$ are reported in parts per million relative to the residual solvent peak or internal standard (tetramethylsilane), and coupling constants $(J)$ are reported in hertz $(\mathrm{Hz})$. High-resolution mass spectra were recorded on a Waters Xevo G2 QTOF LC-MS using ESI. Purity of the products was confirmed by UPLC/MS (the Waters Acquity). Spectral data for final compounds is given below, and data for intermediates are provided in Supplementary information.

\section{Chemical synthesis}

\section{6-Deoxyspectinomycin dihydrochloride (5)}

To a solution of $\mathrm{cbz}$ protected 6-deoxyspectinomycin 16 [20] $(0.080 \mathrm{~g}, 0.136 \mathrm{mmol})$ in $1 \mathrm{M} \mathrm{HCl}$ in $\mathrm{MeOH}(3 \mathrm{ml})$ was added $\mathrm{Pd} / \mathrm{C}(30 \mathrm{mg})$ at room temperature and the reaction mixture was hydrogenated for 30 min under $\mathrm{H}_{2}$ atmosphere ( $\mathrm{H}_{2}$ Balloon). Excess catalyst was filtered off and the evaporation, washing with acetone $(5 \mathrm{ml})$ and EtOAc $(5 \mathrm{ml})$ gave pure product 5 as a white solid. Yield: $0.060 \mathrm{~g}, 81 \%$; ${ }^{1} \mathrm{H}$ NMR (500 MHz, D $\left.2 \mathrm{O}\right) \delta 4.76(\mathrm{~s}, 1 \mathrm{H}), 4.57(\mathrm{~s}, 1 \mathrm{H}), 4.18$ $(\mathrm{t}, J=10.5 \mathrm{~Hz}, 1 \mathrm{H}), 4.07(\mathrm{td}, J=11.3,4.0 \mathrm{~Hz}, 1 \mathrm{H}), 3.92$ $(\mathrm{q}, J=6.6 \mathrm{~Hz}, 1 \mathrm{H}), 3.40-3.32(\mathrm{~m}, 2 \mathrm{H}), 3.28(\mathrm{~s}, 3 \mathrm{H})$, 2.77-2.74 (m, 1H), $2.71(\mathrm{~s}, 3 \mathrm{H}), 1.89-1.72(\mathrm{~m}, 3 \mathrm{H}), 1.17$ $(\mathrm{d}, J=6.2 \mathrm{~Hz}, 3 \mathrm{H}) ;{ }^{13} \mathrm{C} \mathrm{NMR}\left(125 \mathrm{MHz}, \mathrm{D}_{2} \mathrm{O}\right) \delta 93.8$, 93.4, 92.0, 68.4, 67.8, 65.2, 61.1, 59.0, 56.0, 41.5, 30.6, 30.0, 25.5, 19.6. HRMS (ESI) $m / z$ calcd for $\mathrm{C}_{14} \mathrm{H}_{25} \mathrm{~N}_{2} \mathrm{O}_{6}$ $[\mathrm{M}+\mathrm{H}]^{+}, 317.1713$; found, 317.1712.
6-Deoxy-3'-deoxy-3'-dihydro-3'(R)-[(pyridin-2-yl) acetylamino]spectinomycin dihydrochloride (6)

Compound $\mathbf{6}$ was synthesized analogously as $\mathbf{5}$ from 17, as a white solid. Yield: $0.017 \mathrm{~g}(95 \%)$; $\operatorname{IR}_{\text {vmax }}$ (neat): $\mathrm{cm}^{-1}$ 3363, 2973, 1656,1561, 1467, 1166, 1064; ${ }^{1} \mathrm{H}$ NMR (500 $\left.\mathrm{MHz}, \mathrm{D}_{2} \mathrm{O}\right) \delta 8.66(\mathrm{~d}, J=5.8 \mathrm{~Hz}, 1 \mathrm{H}, \operatorname{Ar}-H), 8.47(\mathrm{t}, J=$ $8.0 \mathrm{~Hz}, 1 \mathrm{H}, \mathrm{Ar}-H), 7.95-7.84(\mathrm{~m}, 2 \mathrm{H}, \operatorname{Ar}-H), 4.90(\mathrm{~s}, 1 \mathrm{H})$, $4.56(\mathrm{~s}, 1 \mathrm{H}), 4.26(\mathrm{t}, J=10.4 \mathrm{~Hz}, 1 \mathrm{H}), 4.17-3.96(\mathrm{~m}, 5 \mathrm{H})$, $3.37(\mathrm{~d}, J=11.6 \mathrm{~Hz}, 2 \mathrm{H}), 2.73(\mathrm{~s}, 3 \mathrm{H}), 2.71(\mathrm{~s}, 3 \mathrm{H})$, $2.15(\mathrm{dd}, J=10.6,6.7 \mathrm{~Hz}, 1 \mathrm{H}), 1.83(\mathrm{t}, J=13.5 \mathrm{~Hz}$, 2H), $1.69(\mathrm{~d}, J=14.6 \mathrm{~Hz}, 1 \mathrm{H}), 1.18(\mathrm{~d}, J=6.0 \mathrm{~Hz}, 3 \mathrm{H})$; ${ }^{13} \mathrm{C}$ NMR (125 MHz, $\left.\mathrm{D}_{2} \mathrm{O}\right) \delta 169.0,149.2,146.9,141.4$, $128.3,125.8,93.2,90.2,68.0,67.8,65.3,61.6,58.7,55.9$, 52.3, 39.2, 34.1, 30.6, 30.5, 25.4, 19.8; HRMS (ESI) $m / z$ calcd for $\mathrm{C}_{21} \mathrm{H}_{33} \mathrm{~N}_{4} \mathrm{O}_{6}[\mathrm{M}+\mathrm{H}]^{+}, 437.2400$; found, 437.2393 .

\section{6-Deoxy-3'-dihydro-3'(R)-[(4-fluorobenzyl)aminomethyl] spectinomycin trihydrochloride (7)}

Compound $7(0.011 \mathrm{~g}, 70 \%)$ was synthesized analogously as 6 from 24, as a white solid. Yield: $0.011 \mathrm{~g}(70 \%) ;[\alpha]_{\mathrm{D}}{ }^{28}$ +0.072 (c 0.15, $\mathrm{CH}_{3} \mathrm{OH}$ ); MP: 211.1-211.8; $\mathrm{IR}_{\text {vmax }}$ (neat): $\mathrm{cm}^{-1} 3358,2974,1603,1513,1460,1163,1081 ;{ }^{1} \mathrm{H}$ NMR (500 MHz, $\left.\mathrm{D}_{2} \mathrm{O}\right) \delta 7.46-7.43(\mathrm{~m}, 2 \mathrm{H}, \mathrm{Ar}-H), 7.17-7.14(\mathrm{~m}$, $2 \mathrm{H}, \operatorname{Ar}-H), 4.67(\mathrm{~s}, 1 \mathrm{H}), 4.58(\mathrm{~s}, 1 \mathrm{H}), 4.27(\mathrm{~d}, J=13.5 \mathrm{~Hz}$, $1 \mathrm{H}), 4.20(\mathrm{~d}, J=13.6 \mathrm{~Hz}, 1 \mathrm{H}), 4.18-4.02(\mathrm{~m}, 2 \mathrm{H}), 3.68$ $(\mathrm{dq}, J=12.3,6.1 \mathrm{~Hz}, 1 \mathrm{H}), 3.47-3.26(\mathrm{~m}, 3 \mathrm{H}), 3.13(\mathrm{~d}, J=$ $13.7 \mathrm{~Hz}, 1 \mathrm{H}), 2.73(\mathrm{~s}, 3 \mathrm{H}), 2.71(\mathrm{~s}, 3 \mathrm{H}), 2.14(\mathrm{dt}, J=8.8$, $4.3 \mathrm{~Hz}, 1 \mathrm{H}), 1.88-1.63(\mathrm{~m}, 3 \mathrm{H}), 1.14(\mathrm{~d}, J=5.9 \mathrm{~Hz}, 3 \mathrm{H})$; ${ }^{13} \mathrm{C}$ NMR (125 MHz, D $\left.\mathrm{O}\right) \delta 163.2(\mathrm{~d}, J=247.0 \mathrm{~Hz}, C-\mathrm{F})$, 132.3, 132.2, 125.9, 116.3, 116.1, 93.4, 92.5, 72.2, 67.5, $67.4,65.0,61.2,58.8,55.9,50.8,48.9,40.1,30.5,30.2$, 25.4, 19.8; ${ }^{19} \mathrm{~F}$ NMR ( $\left.{ }_{2} \mathrm{O}, 375 \mathrm{MHz}\right) \delta-112.0$; HRMS (ESI) $m / z$ calcd for $\mathrm{C}_{22} \mathrm{H}_{35} \mathrm{FN}_{3} \mathrm{O}_{6}[\mathrm{M}+\mathrm{H}]^{+}, 456.2510$; found, 456.2510 . 


\section{6-Epi-chloro-6-deoxyspectinomycin dihydrochloride (8)}

Compound 8 was synthesized from cbz-spectinomycin [24]. Yield: $0.012 \mathrm{~g} \mathrm{(42 \% );}{ }^{1} \mathrm{H}$ NMR $\left(500 \mathrm{MHz}, \mathrm{D}_{2} \mathrm{O}\right) \delta 4.93(\mathrm{~s}$, $1 \mathrm{H}), 4.75-4.73(\mathrm{~m}, 1 \mathrm{H}) ; 4.66(\mathrm{t}, J=10.6 \mathrm{~Hz}, 1 \mathrm{H}), 4.44$ (dd, $J=10.5,3.5 \mathrm{~Hz}, 1 \mathrm{H}), 4.05-3.99(\mathrm{~m}, 1 \mathrm{H}), 3.93-3.81(\mathrm{~m}$, $1 \mathrm{H}), 3.54(\mathrm{dd}, J=11.0,3.3 \mathrm{~Hz}, 1 \mathrm{H}), 2.89(\mathrm{~s}, 3 \mathrm{H})$, 2.84-2.83 (m, 1H), 2.81 (s, 3H), 1.95-1.80 (m, 2H), 1.26 $(\mathrm{d}, J=6.3 \mathrm{~Hz}, 3 \mathrm{H}) ;{ }^{13} \mathrm{C} \mathrm{NMR}\left(125 \mathrm{MHz}, \mathrm{D}_{2} \mathrm{O}\right) \delta 93.8$, 93.4, 91.7, 68.6, 66.5, 63.0, 61.6, 58.8, 56.8, 54.4, 41.5, $30.5,30.2,19.5$. HRMS (ESI) $m / z$ calcd for $\mathrm{C}_{14} \mathrm{H}_{24} \mathrm{ClN}_{2} \mathrm{O}_{6}$ $[\mathrm{M}+\mathrm{H}]^{+}, 351.1323$; found, 351.1329.

\section{2-Deoxyspectinomycin dihydrochloride (9)}

Compound 9 [21] was synthesized analogously as 5 from 20, as a white solid. Yield: $0.010 \mathrm{~g}(80 \%){ }^{1} \mathrm{H}$ NMR $(500$ $\left.\mathrm{MHz}, \mathrm{D}_{2} \mathrm{O}\right) \delta 4.77(\mathrm{~s}, 1 \mathrm{H}), 4.04(\mathrm{t}, J=10.3 \mathrm{~Hz}, 1 \mathrm{H})$, $3.96-3.88(\mathrm{~m}, 2 \mathrm{H}), 3.74(\mathrm{t}, J=10.2 \mathrm{~Hz}, 1 \mathrm{H}), 3.46(\mathrm{t}, J=$ $11.6 \mathrm{~Hz}, 1 \mathrm{H}), 3.22(\mathrm{t}, J=10.2 \mathrm{~Hz}, 1 \mathrm{H}), 2.70(\mathrm{~s}, 3 \mathrm{H}), 2.68$ (s, 3H), 2.63-2.57 (m, 1H), 1.81-1.68 (m, 3H), 1.15 (d, $J=$ $6.1 \mathrm{~Hz}, 3 \mathrm{H}) ;{ }^{13} \mathrm{C}$ NMR $\left(125 \mathrm{MHz}, \mathrm{D}_{2} \mathrm{O}\right) \delta$ 93.5, 93.4, 91.6, 69.9, 68.4, 68.2, 68.0, 57.3, 54.3, 41.5, 30.1, 29.7, 23.3, 19.6; HRMS (ESI) $m / z$ calcd for $\mathrm{C}_{14} \mathrm{H}_{25} \mathrm{~N}_{2} \mathrm{O}_{6}[\mathrm{M}+\mathrm{H}]^{+}$, 317.1713; found, 317.1713 .

\section{2-Deoxy-3'-deoxy-3'-dihydro-3' (R)-[(pyridin-2-yl) acetylamino]spectinomycin dihydrochloride (10)}

Compound 10 was synthesized analogously as $\mathbf{6}$ from 21, as a white solid. Yield: $0.010 \mathrm{~g}(79 \%)$; $\mathrm{IR}_{\text {vmax }}$ (neat): $\mathrm{cm}^{-1}$ 3350, 2974, 1648, 1564, 1466, 1168, 1063; ${ }^{1} \mathrm{H}$ NMR (500 $\left.\mathrm{MHz}, \mathrm{D}_{2} \mathrm{O}\right) \delta 8.66(\mathrm{~d}, J=5.9 \mathrm{~Hz}, 1 \mathrm{H}), 8.48(\mathrm{t}, J=8.0 \mathrm{~Hz}$, $1 \mathrm{H}), 8.05-7.81(\mathrm{~m}, 2 \mathrm{H}), 4.93(\mathrm{~s}, 1 \mathrm{H}), 4.27-3.89(\mathrm{~m}, 6 \mathrm{H})$, $3.77(\mathrm{q}, J=9.9,9.2 \mathrm{~Hz}, 1 \mathrm{H}), 3.50(\mathrm{td}, J=11.5,4.1 \mathrm{~Hz}$, $1 \mathrm{H}), 3.25$ (ddd, $J=14.1,10.2,4.3 \mathrm{~Hz}, 1 \mathrm{H}), 2.72$ (s, 3H), 2.71 (s, 3H), 2.68-2.56 (m, 1H), 1.86-1.68 (m, 3H), 1.18 $(\mathrm{d}, J=5.7 \mathrm{~Hz}, 3 \mathrm{H}) ;{ }^{13} \mathrm{C} \mathrm{NMR}\left(125 \mathrm{MHz}, \mathrm{D}_{2} \mathrm{O}\right) \delta 166.3$, $146.5,146.4,144.4,138.7,125.7,123.1,90.3,87.3,67.4$, 65.6, 65.3, 54.6, 51.4, 49.5, 36.5, 31.5, 27.4, 20.9, 17.1, 11.1; HRMS (ESI) $m / z$ calcd for $\mathrm{C}_{21} \mathrm{H}_{33} \mathrm{~N}_{4} \mathrm{O}_{6}[\mathrm{M}+\mathrm{H}]^{+}$, 437.2400; found, 437.2401.

\section{6-Dehydro-3'-deoxy-3'-dihydro-3' (R)-[(5-hydroxypyridin-2- yl)acetylamino]spectinomycin trihydrochloride (11)}

To a mixture of dimethylsulfoxide $(5 \mathrm{ml})$, dry benzene $(5 \mathrm{ml})$, dicyclohexyl carbodiimide $(0.320 \mathrm{~g}, 1.560 \mathrm{mmol})$, and pyridinium trifluoroacetate $(0.050 \mathrm{~g}, 0.260 \mathrm{mmol})$ was added 25 [25] $(0.430 \mathrm{~g}, 0.520 \mathrm{mmol})$. The mixture was stirred at $50{ }^{\circ} \mathrm{C}$ for $4 \mathrm{~h}$. The reaction mixture was then poured into $100 \mathrm{ml}$ of ethyl acetate and $100 \mathrm{ml}$ of water with stirring, the insoluble dicyclohexyl urea was removed by filtration, and the ethyl acetate phase was washed with water and dried over $\mathrm{Na}_{2} \mathrm{SO}_{4}$. After removing solvent, the residue was purified by $\mathrm{C} 18$ chromatography $\left(\mathrm{H}_{2} \mathrm{O} / \mathrm{CH}_{3} \mathrm{CN}\right)$, and $200 \mathrm{mg}(47 \%)$ white solid was obtained as 6-dehydro-cbz25. 6-Dehydro-cbz-25 (157 mg, $0.190 \mathrm{mmol})$ was mixed with $10 \% \mathrm{Pd} / \mathrm{C}(20 \mathrm{mg})$ and $1 \mathrm{M} \mathrm{HCl}$ in $\mathrm{MeOH}(1 \mathrm{ml})$ in $\mathrm{MeOH}(10 \mathrm{ml})$, the mixture was hydrogenated at room temperature for $4 \mathrm{~h}$. $\mathrm{Pd} / \mathrm{C}$ was removed and then the filtrate was dried under vacuum to yield $\mathbf{1 1}$ as a white solid. Yield: $0.080 \mathrm{~g}(73 \%) ; \mathrm{IR}_{\text {vmax }}$ (neat): $\mathrm{cm}^{-1} 3254,2923,2850,1651$, 1552, 1495, 1168, $1067 ;{ }^{1} \mathrm{H}$ NMR $\left(400 \mathrm{MHz}, \mathrm{D}_{2} \mathrm{O}\right) \delta 8.29$ $(\mathrm{d}, J=2.8 \mathrm{~Hz}, 1 \mathrm{H}), 8.02-7.93(\mathrm{~m}, 1 \mathrm{H}), 7.75(\mathrm{~d}, J=8.9 \mathrm{~Hz}$, 1H), 5.14-5.04 (m, 1H), 4.61-4.49 (m, 1H), 4.30-4.03 (m, $6 \mathrm{H}), 3.60(\mathrm{dd}, J=11.2,3.2 \mathrm{~Hz}, 1 \mathrm{H}), 3.51-3.35(\mathrm{~m}, 1 \mathrm{H})$, 2.94-2.84 (m, 6H), 2.03-1.85 (m, 1H), 1.88-1.71 (m, 1H), $1.29(\mathrm{dd}, J=6.1,4.2 \mathrm{~Hz}, 3 \mathrm{H}) ;{ }^{13} \mathrm{C} \mathrm{NMR}\left(125 \mathrm{MHz}, \mathrm{D}_{2} \mathrm{O}\right) \delta$ $169.6,169.5,154.9,140.3,133.5,133.5,129.2,129.2$, 129.0, 128.9, 94.1, 93.9, 93.2, 93.0, 92.2, 92.1, 90.2, $90.0,89.8,71.8,70.8,69.9,68.4,67.2,64.7,61.8,60.1$, 58.3, 57.8, 54.0, 52.2, 48.8, 38.2, 34.1, 30.8, 30.7, 30.2, 30.0, 19.8, 19.8. HRMS (ESI) $m / z$ calcd for $\mathrm{C}_{21} \mathrm{H}_{31} \mathrm{~N}_{4} \mathrm{O}_{8}$ $[\mathrm{M}+\mathrm{H}]^{+}$, 467.2142; found, 467.2144.

\section{Molecular modeling}

\section{Mycobacterial RNA-RpsE protein complex generation}

The molecular docking and molecular dynamics studies of spectinomycin and spectinomycin analogs were performed using a comparative model of the $M$. tuberculosis RNARpsE protein complex prepared using the Escherichia coli complex as a template. The Mycobacterial RpsE proteins (M. tuberculosis and Mycobacterium smegmatis) have a high degree of homology, with $89 \%$ sequence similarity. The differences in the RpsE protein sequences lie outside the spectinomycin binding site on the RpsE loop (Fig. 4). Therefore, the M. tuberculosis RpsE protein sequence was used to create a Mycobacterial RNA-RpsE protein complex for molecular modeling of both species. The E. coli RpsE protein structure (PDB ID: 4V56 (2QOU)) served as the structural template to generate the model, 55\% homology [26]. The model was created using Schrödinger's Prime program [27, 28] and was validated in PROCHECK [29] with $2.7 \%$ residues allowed and $0 \%$ disallowed (data not shown). A sequence alignment of RpsE proteins from the Mycobacteria and E. coli revealed two amino acid differences located in the RpsE protein loop in the spectinomycin binding site: V55T and R61I (Fig. 4). Despite variations in the RpsE protein, the rRNA sequence found in the spectinomycin binding site is highly conserved between Mycobacteria and $E$. coli. To reduce the computational cost of subsequent molecular docking and molecular simulations, the complex model was truncated to a $20 \AA$ sphere around 
Fig. 4 Alignment of E. coli, $M$. tuberculosis, and M. smegmatis RpsE protein. a The alignment of the protein structures of the RpsE protein from E. coli from PDB ID 2QOU [26] (orange), the homology model from $M$. tuberculosis (blue), and $M$. smegmatis (green) developed in Schrödinger using Prime $[27,28]$. Residues that are different in the RpsE protein loop between species are shown as sticks and are labeled. $\mathbf{b}$ The sequence alignment of the RpsE proteins $[49,50]$. Black highlights represent identical residues, gray highlights represent similar residues, and the red boxes highlight the RpsE protein loop a

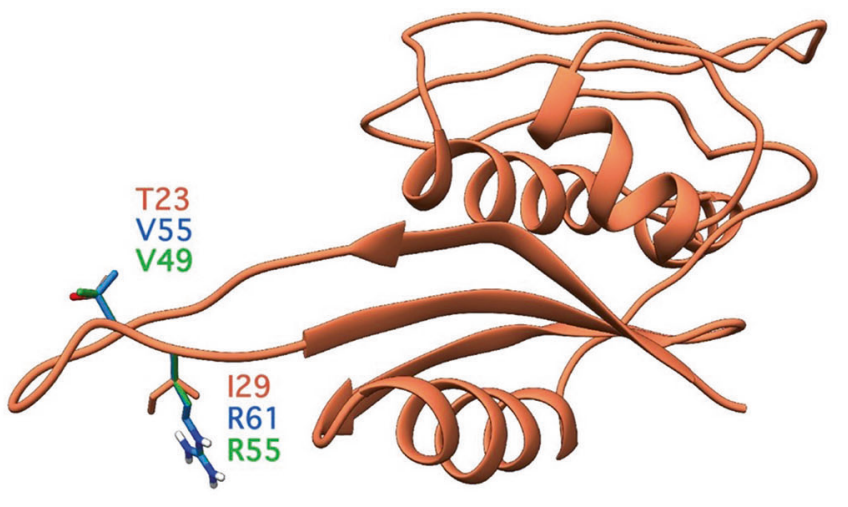

b E.coli M.tuberculosis M. smegmatis

E.coli M.tuberculosis M. smegmatis

E. coli

M.tuberculosis M. smegmatis

E.coli

M.tuberculosis M. smegmatis

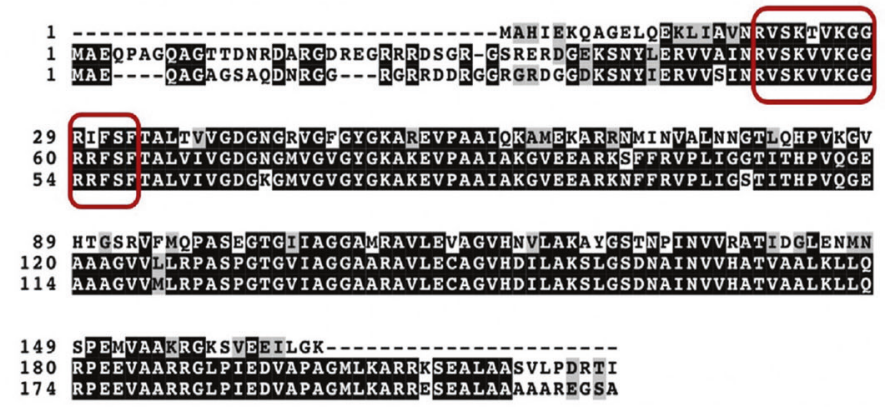

the spectinomycin binding site. The Mycobacterial RNARpsE complex was protonated at $\mathrm{pH} 7.0$ using PROPKA and was energy minimized with the OPLS3 force field $[30,31]$.

\section{Ligand preparation}

SMILES strings for spectinomycin and analogs were used to render 3D conformations of the compounds in Schrödinger. Minimum energy conformations of each analog were generated by LigPrep using the OPLS3 force field [30]. Specified chiralities were retained and the ionization states at a target $\mathrm{pH} 7.0 \pm 2.0$ were generated using Epik [32].

\section{Receptor grid generation}

For the molecular docking of spectinomycin and analogs, a receptor grid was generated using Schrödinger's Glide program [33-35]. A cubic box was positioned in the center of the spectinomycin binding site. The inner box was set to $10 \times 10 \times 10 \AA$ and the outer box was $30 \times 30 \times 30 \AA$. This larger box was designed to permit the docking of spectinamides and amSPCs in the binding site. The spectinomycin binding site determined by X-ray crystallography (PDB ID 2QOU) [26] revealed a series of hydrogen bond interactions from the rRNA nucleotides. Therefore, hydrogen bonding constraints were generated for residues G1064, C1066, G1068, A1191, C1192, and G1193 for a datadriven docking approach.

\section{Glide standard precision molecular docking}

All conformations generated from LigPrep were docked using Schrödinger's Glide program [33-35]. Ligand sampling was flexible, and docked conformers were required to match at least one hydrogen bonding interaction from the constraints generated in the receptor grid. To soften the potential for nonpolar parts of the ligands, van der Waals (VDW) radii were scaled using a scaling factor of 0.80 for ligand atoms with a partial charge $<0.15$ (default Glide settings). Post-docking minimization was performed on all poses generated by Glide using the OPLS3 force field prior to the assignment of Glide docking scores. Ligand poses with the highest ranked Glide scores were used to evaluate binding. The highest ranked analogs, 1 (spectinomycin), 2, $5,6,9$, and 10, were advanced to molecular dynamics simulations.

\section{Molecular dynamics}

All molecular dynamic simulations were performed using AMBER18 [36] as previously described [25]. Briefly, the ff14SB and OL3 force field was used for the RNA and protein parameterization and the general Amber force field was used for parameterization of the ligand [37-39]. Restrained electrostatic potential charges within the ANTECHAMBER module in AMBER were applied to the positively charged spectinomycin, 2, 5, 6, 9, and 10 analogs. Sodium ions were applied to neutralize the charge of 
the system. The complex was solvated in a TIP3P octahedron box with a $10 \AA$ boundary. An initial energy minimization of the solvated complex was performed with the complex fixed for 1000 steps, followed by a second step of energy minimization without restraints for 2500 steps. The minimized complex was equilibrated to $300 \mathrm{~K}$ over 250,000 steps for 500 ps with weak restraints applied to the complex (Fig. S1). The equilibrated structure was simulated for $20 \mathrm{~ns}$ with the NPT ensemble at $300 \mathrm{~K}$ with terminal residues harmonically restrained (Fig. S1). The energetic contributions during the MD simulations were calculated by the MM/GBSA [40] method using 1000 frames from the last $2 \mathrm{~ns}$ of the MD ensemble. Lastly, the free energy contributions to ligand binding were decomposed for analysis using a per-residue basis [40].

\section{Ribosomal inhibition}

Purified 70S M. smegmatis bacterial ribosomes were used in translation reactions. Firefly luciferase mRNA was produced in vitro using T7 RNA polymerase. Translation reactions were carried out as previously described [11]. The $\mathrm{IC}_{50}$ values represent the drug concentration that inhibits luciferase activity by $50 \%$.

\section{Bacterial strains and growth conditions}

Strains were routinely grown with Mueller-Hinton broth at $37^{\circ} \mathrm{C}$ with shaking at $225 \mathrm{rpm}$. Bacterial strains were obtained through ATCC or BEI Resources or from academic laboratories. The strains used were the following: Staphylococcus aureus ATCC 29213, S. aureus NRS70, Enterococcus faecalis ATCC 33186, E. faecium ATCC 19434, Streptococcus pyogenes ATCC 700294, Streptococcus pneumoniae R6, Acinetobacter baumannii ATCC 19606, Pseudomonas aeruginosa ATCC 15692, Klebsiella pneumoniae ATCC 700603, Proteus mirabilis ATCC 25933, Stenotrophomonas maltophilia ATCC 13637, Enterobacter cloacae ATCC 13047, Staphylococcus epidermidis ATCC 14990, E. coli K12, and E. coli JW5503 ( $\Delta$ tolC). The M. tuberculosis H37Rv strain was grown in Middlebrook $7 \mathrm{H} 9$ broth supplemented with $10 \%$ albumin-dextrose complex, $0.05 \%$ (v/v) Tween 80 at $\mathrm{pH}$ 7.4, (7H9/ADG pH 7.4) with shaking at $225 \mathrm{rpm}$ at $37^{\circ} \mathrm{C}$.

\section{Antibacterial susceptibility testing}

Minimum inhibitory concentrations are determined following CLSI broth microdilution guidelines [41]. Briefly, experimental compounds (in DMSO) and control spectinomycin (Sigma Aldrich, DMSO) are serially diluted, twofold, across a 96-well round bottom plate in Mueller-Hinton II broth or 7H9/ADG pH 7.4 for
M. tuberculosis H37Rv. Equal volume of bacterial strains of $5 \times 10^{5} \mathrm{CFU} \mathrm{ml}{ }^{-1}$ was added to each well to give a final drug concentration starting at $200 \mu \mathrm{g} \mathrm{ml}^{-1}$. Plates were incubated for $18 \mathrm{~h}$ at $37^{\circ} \mathrm{C}$ except M. tuberculosis H37Rv, which was incubated for 7 days at $37^{\circ} \mathrm{C}$. The MIC for all strains were determined as the lowest concentration to visually inhibit bacterial growth and are reported as the consensus of three independent experiments.

\section{Whole-cell accumulation assay}

Methods for this assay have been optimized from previously published studies [42, 43]. E. coli (BW25113 for WT or JW5503 for $\Delta$ tolC) is grown at $37{ }^{\circ} \mathrm{C}$ to mid-log phase (OD600 of 0.6-0.7) in Mueller-Hinton broth. The bacteria are pelleted and washed twice with PBS before being resuspended in $3.5 \mathrm{ml}$ of PBS per $100 \mathrm{ml}$ of cells cultured. Cells are allowed to equilibrate for $10 \mathrm{~min}$ at $37^{\circ} \mathrm{C}$ prior to drugging. $1 \mathrm{ml}$ of $E$. coli is incubated with a final concentration of $50 \mu \mathrm{M}$ of compound (in DMSO) shaking at $37^{\circ} \mathrm{C}$ for $10 \mathrm{~min}$. $800 \mu \mathrm{l}$ of treated cells is layered over supercooled $\left(-78^{\circ} \mathrm{C}\right)$ silicone oil (9:1 AR20 and high-temperature silicone oil, Sigma Aldrich) and pelleted to remove cells from free compound. For lysis, the pellets were resuspended in $200 \mu$ of HPLC grade water and subjected to three freeze-thaw cycles using liquid nitrogen and a $65^{\circ} \mathrm{C}$ water bath. Cell debris was separated from lysate by centrifugation, and $150 \mu \mathrm{l}$ of extract is recovered. The pellet is resuspended in the remaining $50 \mu \mathrm{l}$ of water, and once thoroughly resuspended, $100 \mu \mathrm{l}$ of $5 \%$ TCA was added. The cells are once again pelleted, and lysates are combined. Lysates are pelleted at high speed for $10 \mathrm{~min}$ and then filtered through a $0.22 \mu \mathrm{m}$ filter before injection for LC-MS/MS.

Samples are analyzed with a tandem Waters Acquity M Class series UPLC system and Xevo G2 QTOF tandem MS/ MS with Zspray. $100 \mathrm{nl}$ of extract was separated using a Phenomenex Kinetex 2.6 $\mu \mathrm{m}$ XB-C18, $100 \AA(300 \mu \mathrm{m} \times$ $150 \mathrm{~mm}$ ) column with solvent A, $0.1 \%$ formic acid in water, and solvent $\mathrm{B}, 0.1 \%$ formic acid in acetonitrile. The inlet method for these samples utilized a flow rate of $8 \mu \mathrm{l} \mathrm{min}{ }^{-1}$ with the following gradient: $0-4 \mathrm{~min}, 99.9 \%$ solvent $\mathrm{A}$ and $0.1 \%$ solvent $\mathrm{B} ; 4-5 \mathrm{~min}, 10 \%$ solvent $\mathrm{A}$ and $90 \%$ solvent B; 5-6 min, $99.9 \%$ solvent A and $0.1 \%$ solvent B. Tandem mass spectra were acquired with a cone voltage and collision energy optimized for each compound. High-resolution spectra were calibrated by co-infusion of $2 \mathrm{ng} \mathrm{ml}^{-1}$ leucine enkephalin lockspray (Waters). Data were quantified using Waters MassLynx software where the AUC was determined by integrating the corresponding daughter peak of the parent compound. Concentrations of the unknown compounds were determined by the linear fit of the corresponding standards. Concentrations are reported as the average of three biological replicates. 


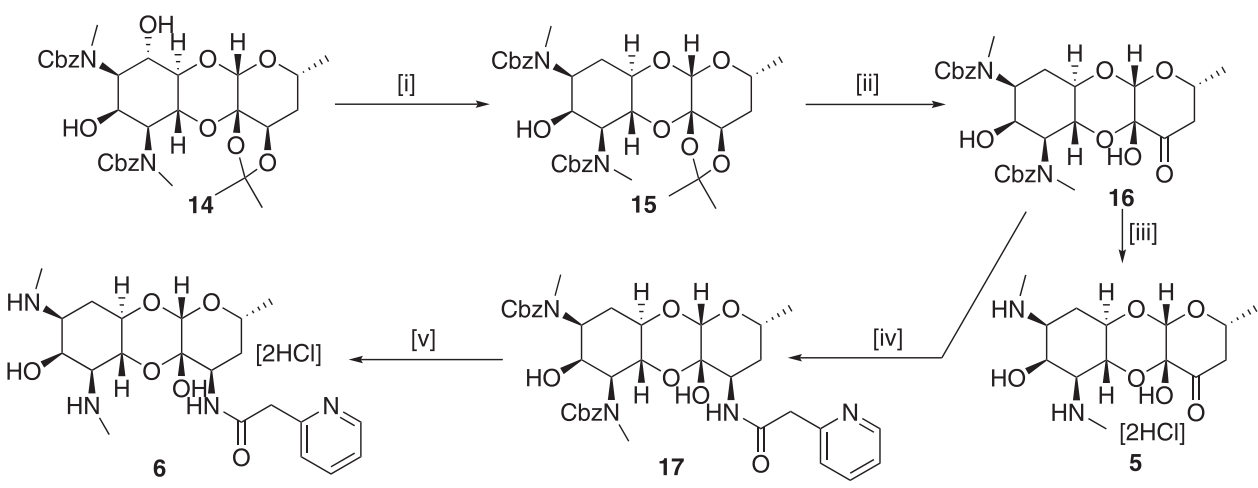

Scheme 1 Synthesis of 6-deoxyspectinomycin 5 and 6deoxyspectinamide 6. Reagents and conditions: [i] (a) 1,1'-Thiocarbonyldiimidazole, DMAP, DCM, (b) $\mathrm{Bu}_{3} \mathrm{Sn}-\mathrm{H} / \mathrm{AIBN}$, Toluene, 55\% over two steps; [ii] (a) $1 \mathrm{M} \mathrm{HCl}$ in $\mathrm{MeOH}$, (b) IBX, DMSO, $85 \%$ over two steps; [iii] $\mathrm{Pd} / \mathrm{C}-\mathrm{H}_{2}, \mathrm{MeOH}, 81 \%$; [iv] (a) $\mathrm{NH}_{4} \mathrm{NO}_{3} /$ $\mathrm{CH}_{3} \mathrm{COOH}$, 2-picoline-borane complex, $\mathrm{MeOH}$, (b) 2-Pyridylacetic acid hydrochloride, HBTU, DMF, $25 \%$ over two steps; [v] Pd/C- $\mathrm{H}_{2}$, $\mathrm{MeOH}, 95 \%$
Scheme 2 Synthesis of 2deoxyspectinomycin 9 and 2deoxyspectinamide 10. Reagents and conditions: [i] (a) $\mathrm{NaH}$, $\mathrm{BnBr}, \mathrm{THF}$, (b) $1 \mathrm{M} \mathrm{HCl}$ in $\mathrm{MeOH}, 65 \%$ over two steps; [ii] IBX, DMSO; 86\% [iii] Pd/C- $\mathrm{H}_{2}$, $\mathrm{MeOH}, 80 \%$; [iv] (a) $\mathrm{NH}_{4} \mathrm{NO}_{3} /$ $\mathrm{CH}_{3} \mathrm{COOH}$, 2-picoline-borane complex, $\mathrm{MeOH}$, (b) 2Pyridylacetic acid hydrochloride, HBTU, DMF, $34 \%$ over 2 steps; [v] Pd/C- $\mathrm{H}_{2}$, $1 \mathrm{M} \mathrm{HCl}$ in $\mathrm{MeOH}, 79 \%$

\section{Results and discussion}

\section{Synthesis}

Adapting literature procedures, compound 14 [22, 44] was synthesized from spectinomycin via catalytic hydrogenation of keto group, cbz protection of amines, and diacetonide protection diol. Deoxygenation at C-6 position in compound 14 was achieved efficiently by following Barton's radical deoxygenation [23] method (Scheme 1). Thus, selective installation of imidazolyl thiocarbamate group on C-6-hydroxy group was carried out using 1,1'thiocarbonyldimimidazole in the presence of catalytic amount of DMAP and treatment of thiocarbamate with tributyltin hydride and AIBN gave deoxygenated product $\mathbf{1 5}$ in good yields. An acetonide group was removed under $1 \mathrm{M} \mathrm{HCl}$ in methanol to give diol and selective oxidation of 4'-hydroxy group with IBX yielded cbz protected 6deoxyspectinomycin 16. Lastly, compound 16 was converted to 6-deoxyspectinomycin [20] $\mathbf{5}$ by removal cbz group under catalytic hydrogenation (Scheme 1). To achieve 6deoxyspectinamide $\mathbf{6}$, compound $\mathbf{1 6}$ underwent reductive amination reaction with ammonium nitrate and 2-picolineborane complex to provide $4^{\prime} R$-amino-6-deoxyspectinomycin, which then coupled with 2-pyridyl acetic acid to give compound $17[45,46]$. The newly generated stereochemistry on the $3^{\prime}(R)$ position was assigned using coupling constant $\left(J_{3^{\prime} 4^{\prime} \mathrm{ax}}=4.4 \mathrm{~Hz} ; J_{3^{\prime} 4^{\prime} \mathrm{eq}}=2.3 \mathrm{~Hz}\right)$ [47] values between $3^{\prime}$ and $4^{\prime}$ hydrogens by synthesizing compound 16b (data available in Supplementary Scheme 1, compound 16b). Finally, catalytic hydrogenolysis of cbz product of $\mathbf{1 7}$ under $\mathrm{Pd} / \mathrm{C}$ gave 6-deoxyspectinamide $\mathbf{6}$.

Attempts to deoxygenation of C-2-hydroxy group using the Barton imidazolylthiocarbamate intermediate failed presumably due to the steric hindrance of C-2-hydroxy group, we consequently followed literature procedure to make 2-deoxyspectinomycin. The 2-deoxyderivative $\mathbf{1 8}$ was achieved from spectinomycin using the protocol of Foley et al. (Scheme 2) [21]. Benzyl protection of 6hydroxy group followed by removal of acetonide group yielded diol 19. Compound 9 was achieved by oxidation of compound $\mathbf{1 9}$ to give compound $\mathbf{2 0}$ and followed by cbz group deprotection. The 2-deoxyspectinamide $\mathbf{1 0}$ was synthesized from $\mathbf{2 0}$ via $\mathbf{2 1}$ following similar protocol [45] as used in $\mathbf{6}$.

6-Deoxy-amSPC 7 was synthesized from amSPC intermediate 22 [11]. First, the benzyl amine group in 22 [11] was protected as tert-butyl carbamate derivative and then the 
Scheme 3 Synthesis of 6-deoxyamSPC 7. Reagents and conditions: [i] (a) $(\mathrm{Boc})_{2} \mathrm{O}$, $\mathrm{Et}_{3} \mathrm{~N}, \mathrm{MeOH}$, (b) 1,1'-

Thiocarbonyldiimidazole, DMAP, DCM, $71 \%$ overs two steps; [ii] (a) $\mathrm{Bu}_{3} \mathrm{Sn}-\mathrm{H} / \mathrm{AIBN}$, Toluene, (b) TFA, DCM, 41\% over two steps; [iii] $\mathrm{Pd} / \mathrm{C}-\mathrm{H}_{2}, 1$ $\mathrm{M} \mathrm{HCl}$ in $\mathrm{MeOH}, 70 \%$

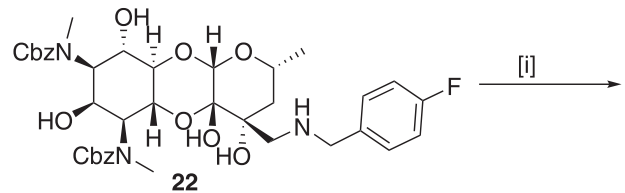

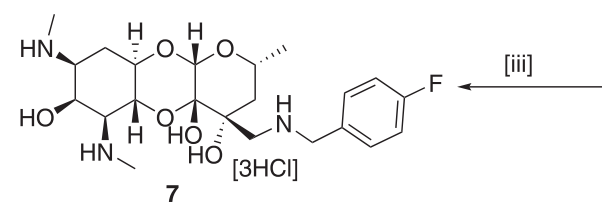

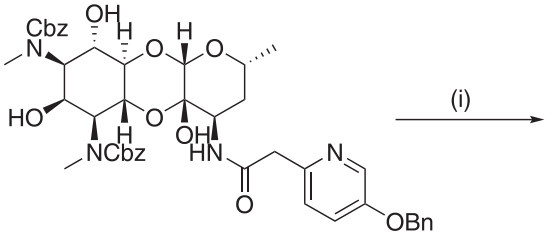
25
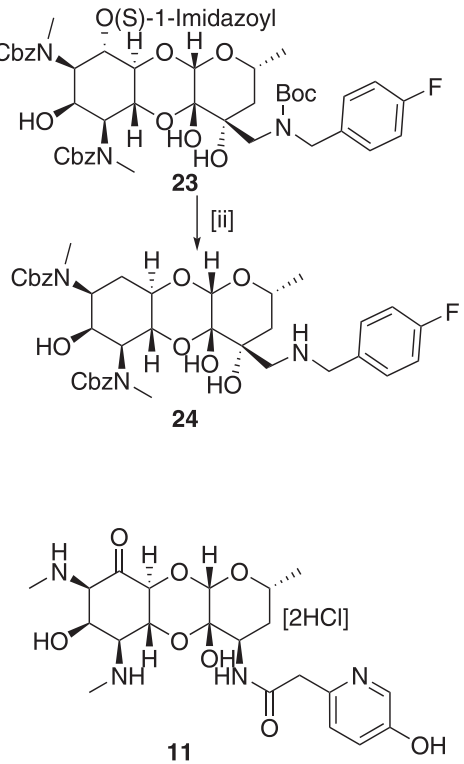

Scheme 4 Synthesis of 6dehydrospectinamide $\mathbf{1 1}$. Reagents and conditions: [i] (a) pyridinium trifluoroacetate, dicyclohexyl carbodiimide, DMSO, $50{ }^{\circ} \mathrm{C}$, (b) $10 \% \mathrm{Pd} / \mathrm{C}-$ $\mathrm{H}_{2}, 0.1 \mathrm{M} \mathrm{HCl}$ in $\mathrm{MeOH}, 73 \%$ 6-imidazolylthiocarbamate derivative $\mathbf{2 3}$ was synthesized using 1,1'-thiocarbonyl diimidazole. Deoxygenation at C-6 position was then achieved efficiently by following Barton's radical deoxygenation [23] method as used in compound $\mathbf{1 5}$ to give deoxygenated product $\mathbf{2 4}$ in moderate yield. Finally, deoxy compound 7 was achieved by removing tert-butoxy carbonyl group using trifluoroacetic acid and benzyloxy carbonyl group deprotection under hydrogenolysis condition (Scheme 3). The 6-epi-chloro compound 8 was synthesized following literature protocol [24]. The synthesis of 6dehydrospectinamide $\mathbf{1 1}$ was accomplished from cbz protected 25 [25] via selective oxidation of C-6-hydroxy group by Pfitzner-Moffatt method and followed hydrogenolytic deprotection of cbz groups (Scheme 4).

\section{Antibacterial susceptibility and ribosomal activity of deoxy analogs}

The antibacterial susceptibilities of the synthesized deoxy analogs were tested against a panel of Gram (+) and Gram (-) pathogens, plus M. tuberculosis (abbreviated in Table 1, full data available in Supplementary Table 1). All deoxyspectinomycin analogs lacked MIC activity in line with previous reports [20]. Deoxyspectinamides 6 and 10 and deoxy-amSPC 7 had some limited MIC activity against $M$. tuberculosis and $S$. pneumoniae, weaker than their corresponding parent spectinamide $\mathbf{2}$ and $\operatorname{amSPC} \mathbf{3}$, consistent with their reduced ribosomal binding affinities described subsequently.

The ability of the analogs to inhibit ribosomal translation was performed with $M$. smegmatis ribosomes in a cell-free translation assay [11] (Table 1). The 6- and 2-deoxyspectinomycins, $\mathbf{5}$ and $\mathbf{9}$, show poor ribosomal binding inhibition (Ribo $\mathrm{IC}_{50}>60 \mu \mathrm{g} \mathrm{ml}^{-1}$ ) compared to spectinomycin 1 (Ribo $\mathrm{IC}_{50} 0.36 \mu \mathrm{g} \mathrm{ml}^{-1}$ ). The molecular docking of 5 and 9 suggests that the hydrogen bonding interactions from the 6- and 2-hydroxy groups are crucial for ribosomal binding inhibition (Fig. S2A, B). Substitution of the hydroxy group at the 6-position on spectinomycin was tested to determine if the loss in activity could be rescued while avoiding AME activity. However, addition of a chlorine at the 6-position (8) maintained poor activity (Table 1) and disrupted the majority of hydrogen bonding interactions involved with spectinomycin binding (Fig. S2C). Therefore, the hydroxy group at the 6-position of spectinomycin forms hydrogen bonding interactions that are crucial to maintain ribosomal inhibition.

The 6-deoxyspectinamide 6 showed improved ribosomal inhibition compared to $\mathbf{5}$, ( $\operatorname{Ribo} \mathrm{IC}_{50}=9.50 \mu \mathrm{g} \mathrm{ml}^{-1}$ ) suggesting the aryl side chain could partially rescue inhibitor activity. The aryl side chain extends from the spectinomycin binding site and interacts directly with the RpsE protein loop through VDW interactions (Fig. S3). Similarly, 6deoxy-amSPC 7 had improved ribosomal inhibition (Ribo $\mathrm{IC}_{50}=23.3 \mu \mathrm{g} \mathrm{ml}^{-1}$ ) from the contribution of the aryl side chain (Fig. S4). This feature may be used in part to compensate for the loss of hydrogen bonding interaction with the spectinomycin core and the bacterial ribosome, a phenomenon that could not be observed in $\mathbf{5}$ as it lacks the aryl side chain. 2-Deoxyspectinamide $\mathbf{1 0}$ also showed improved ribosomal inhibition ( $\mathrm{Ribo} \mathrm{IC}_{50}=10.2 \mu \mathrm{g} \mathrm{ml}^{-1}$ ) compared to the 2-deoxyspectinomycin 9 (Ribo $\mathrm{IC}_{50}>60 \mu \mathrm{g} \mathrm{ml}^{-1}$ ). From the molecular docking of $\mathbf{1 0}$, the aryl side chain is also shown to gain interactions with the RpsE protein backbone, providing further evidence that aryl side chain rescues ribosomal binding (Fig. S3). 
Table 1 Antibacterial susceptibility (MIC, $\mu \mathrm{g} \mathrm{ml}^{-1}$ ) and ribosomal affinity $\mathrm{IC}_{50}\left(\mu \mathrm{g} \mathrm{ml}{ }^{-1}\right.$ ) studies of synthesized compounds

\begin{tabular}{|c|c|c|c|c|c|}
\hline Compounds & $\begin{array}{l}\text { M. tuberculosis H37Rv } \\
\text { MIC }\left(\mu \mathrm{gl}^{-1}\right)\end{array}$ & $\begin{array}{l}\text { S. pneumoniae R6 } \\
\operatorname{MIC}\left(\mu \mathrm{g} \mathrm{ml}^{-1}\right)\end{array}$ & $\begin{array}{l}\text { E. coli K-12 MIC } \\
\left(\mu \mathrm{g} \mathrm{ml}^{-1}\right)\end{array}$ & $\begin{array}{l}\text { E. coli cellular } \\
\text { accumulation }(\mu \mathrm{M})\end{array}$ & $\begin{array}{l}\text { Ribosome translation } \\
\text { inhibition } \mathrm{IC}_{50}\left(\mu \mathrm{g} \mathrm{ml}^{-1}\right)\end{array}$ \\
\hline & 50 & 12.5 & 25 & $1.1 \pm 0.1$ & 0.36 \\
\hline
\end{tabular}

Spectinomycin (1)<smiles>CN[C@H]1[C@@H](O)[C@@H](NC)[C@H](O)[C@@H]2O[C@@H]3O[C@H](C)C[C@H](NC(=O)Cc4ccccn4)[C@]3(O)O[C@H]12</smiles><smiles>CN[C@H]1[C@@H](O)[C@@H](NC)[C@]2(O[C@@H]3O[C@H](C)C[C@@](O)(CNCc4ccc(F)cc4)[C@]3(O)O2)[C@@H]1O</smiles>

3<smiles>CN[C@H]1[C@@H](O)[C@@H](NC)[C@H](O)[C@@H]2O[C@H]3O[C@H](C)C[C@H](NC(=O)Cc4ccc(O)cn4)[C@]3(O)O[C@H]12</smiles>

4<smiles>CN[C@H]1C[C@H]2O[C@H]3O[C@H](C)CC(=O)[C@@]3(O)O[C@H]2[C@H](NC)[C@@H]1O</smiles><smiles>CN[C@H]1C[C@H]2O[C@@H]3O[C@H](C)C[C@H](NC(=O)Cc4ccccn4)[C@]3(O)O[C@]2(C)[C@H](NC)[C@@H]1O</smiles> 
Table 1 (continued)

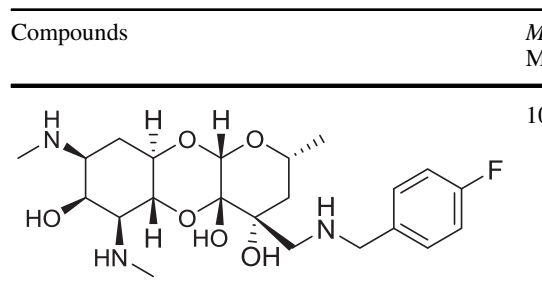

$M$ tuberculosis $\mathrm{H} 37 \mathrm{Rv} \quad S$, pneumoniae R6 $\operatorname{MIC}\left(\mu \mathrm{g} \mathrm{ml}^{-1}\right)$

100 $\operatorname{MIC}\left(\mu \mathrm{g} \mathrm{ml}^{-1}\right)$
E. coli $\mathrm{K}$
$\left(\mu \mathrm{g} \mathrm{ml} \mathrm{m}^{-1}\right)$

$>200$
E. coli cellular accumulation $(\mu \mathrm{M})$

$47+1$
Ribosome translation inhibition $\mathrm{IC}_{50}\left(\mu \mathrm{g} \mathrm{ml}^{-1}\right)$

7<smiles>CN[C@@H]1[C@H](Cl)[C@@H]2O[C@@H]3O[C@H](C)CC(=O)[C@]3(O)O[C@@H]2[C@@H](NC)[C@H]1O</smiles><smiles>CN[C@H]1C[C@H](NC)[C@H]2O[C@@H]3O[C@H](C)CC(=O)[C@]3(O)O[C@H]2[C@H]1O</smiles><smiles>CN[C@H]1C[C@H](NC)[C@@]2(O[C@@]3(O)C(NC(=O)Cc4ccccn4)C[C@H](C)O[C@H]3[C@@H]2O)[C@H]1O</smiles><smiles>CN[C@H]1C(=O)[C@@H]2O[C@@H]3O[C@H](C)CC(NC(=O)Cc4ccc(O)cn4)[C@@]3(O)O[C@H]2[C@H](NC)[C@@H]1O</smiles>

11

In the case of the 6-dehydrospectinamide 11, we observed an increase in ribosomal binding affinity compared to other 6-deoxy analogs $\left(\right.$ Ribo $\mathrm{IC}_{50}=34.7 \mu \mathrm{g} \mathrm{ml}^{-1}$ ). The molecular docking studies of the parent compound, 4, and the $\mathbf{1 1}$ analog reveal the carbonyl at the 6-position docked with a similar predicted affinity (Fig. S5). The exact molecular entity of $\mathbf{1 1}$ is not known in solution state at this stage as it likely exists in equilibrium with its hydrated form as indicated by its ${ }^{13} \mathrm{C}$ NMR (Fig. 3). Therefore, we also docked the 12 (gem-diol-11) (Fig. S5). This analog exhibited two hydrogen bond interactions with G1064 and G1193, but loses the hydrogen bonding interaction with the backbone of Arg60 and has a weaker docking score compared to 4 and 11 (Fig. S5). These results point to reason 


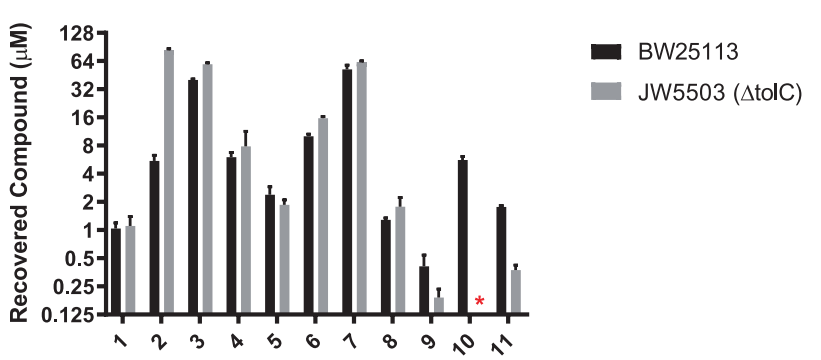

Fig. 5 Whole-cell accumulation assay tested per compound in wildtype E. coli. (BW25113) and $\Delta$ tolc (JW5503) strains. *Not determined

for the weak binding (Ribo $\mathrm{IC}_{50}=34.7 \mu \mathrm{g} \mathrm{ml}^{-1}$ ) for $\mathbf{1 1}$ compared to 4 (Ribo $\mathrm{IC}_{50}=0.84 \mu \mathrm{g} \mathrm{ml}^{-1}$ ) is due to $\mathbf{1 2}$ (gem-diol-11) being the dominant binding isoform.

\section{Cellular accumulation}

To examine if altered cellular accumulation contributes to reduced MIC activity of deoxyspectinomycin analogs, the concentration of all analogs within $E$. coli cells was measured and compared to their corresponding spectinomycin family parent (Fig. 5 and Table S3) [43]. These experiments indicated a substantial difference in the accumulation between the different families, spectinomycins $(\mathbf{1}, \mathbf{5}, \mathbf{8}, \mathbf{9}$; range $<0.4$ to $1.2 \mu \mathrm{M})$, spectinamides $(\mathbf{2}, \mathbf{4}, \mathbf{6}, \mathbf{1 0}$; range $<5.4$ to $10 \mu \mathrm{M})$, and amSPCs $(\mathbf{3}, \mathbf{7} ; 40$ and $47 \mu \mathrm{M}$, respectively). When examining matched pairs within families (1 vs 5 and $9 ; 2$ vs 6 and $10 ; 3$ vs 7 ), deoxygenation led to a slight increase in accumulation, with the most pronounced effect for 6-deoxy analogs. The increased accumulation is, however, modest and unlikely to impact MIC levels. The pattern of uptake was generally mirrored in the E. coli $\Delta$ tolC strain. However, these data suggest that the early spectinamide, $\mathbf{2}$, is subjected to efflux by tolC. The depletion of the efflux pump results in a 15 -fold increase in intracellular accumulation, which matches the trends in susceptibility where knocking out the efflux pump reduces the MIC of 2 from 200 to $50 \mu \mathrm{g} \mathrm{ml}^{-1}$. Overall, these results indicate that altered accumulation does not affect the antimicrobial potency among the deoxyspectinomycin analogs.

\section{Molecular dynamics simulations}

Spectinomycin binding is mediated through a complex pattern of hydrogen bond interactions between the rRNA nucleotides and the ligand [26]. A better understanding of the contributions of the 2- and 6-hydroxy group positions on the spectinomycin scaffold is crucial for the development of novel analogs that overcome inactivation by AMEs. We chose to examine these interactions using molecular dynamics simulations, rather than the rigid body docking used earlier in this paper. These are computationally intense experiments that account for dynamically changing interactions between the ligand, rRNA nucleotides, RpsE loop, and associated water molecules. Removing or modifying the 2- and 6-hydroxy groups on spectinomycin and analogs had large effect on the binding and antibacterial activity (Table 1). To examine the molecular basis of these effects, the docked conformations of spectinomycin $\mathbf{2}, \mathbf{5 , 6}$, 9, and $\mathbf{1 0}$ analogs were subjected to a $20 \mathrm{~ns}$ molecular dynamic simulation (Figs. 6 and 7). The docking pose of spectinomycin into the M. tuberculosis rRNA/RpsE complex homology model was compared to the E. coli X-ray crystal structure (PDB ID: 2QOU [26]) to ensure the binding mode was not altered between species. The ligand RMSD between the two structures was $0.65 \AA$ (data not shown). The final spectinomycin binding mode following a $20 \mathrm{~ns}$ MD simulation is shown (Fig. 6). Like the X-ray crystal structure, the nucleotides in the spectinomycin binding pocket participate in several key hydrogen bonding interactions. The 2-hydroxy group coordinates with a water molecule and interacts with A1191, while the 6-hydroxy group has one binding interaction with G1064.

In the simulation, 6-deoxyspectinomycin 5 lost the 6hydroxy group-mediated hydrogen bonding interaction with the G1064 nucleotide (Fig. 6b) and resulted in a $1.65 \AA$ RMSD shift in the pocket compared to spectinomycin (Fig. 6d). The free energy of binding for spectinomycin and analogs was calculated using MM/GBSA in Amber18 [40] (Table 2). The MM/GBSA method calculates binding free energies using molecular mechanics at low computational cost $[40,48]$. Furthermore, GBSA is accurate and robust in ranking binding affinities for structure-based drug discovery. Removal of the 6-hydroxyl group resulted in a decrease of $8.6 \mathrm{kcal} \mathrm{mol}^{-1}$ in binding energy compared to spectinomycin and is reflective of the poor $\mathrm{IC}_{50}$. Removal of the 2-hydroxy in 9 results in the loss of two hydrogen bonding interactions in the pocket, i.e., a water molecule and the A1191 nucleotide (Fig. 6c). Despite the remaining hydrogen bonding partners, 9 produces a larger shift in the pocket with a RMSD of $2.81 \AA$ (Fig. 6d). This shift results in a $6.3 \mathrm{kcal} \mathrm{mol}^{-1}$ decrease in the binding energy compared to spectinomycin (Table 2). While both analogs had poor binding affinities, loss of the 2-hydroxy group was more favorable than the 6-hydroxy group for the spectinomycin core.

Interactions driving spectinomycin binding are also observed in the spectinamide 2-bound complex, with the addition of a hydrogen bond between the aryl chain on spectinamide and G1193 (Fig. 7a). The aryl chain also gains VDW interactions on the RpsE protein loop. Binding of $\mathbf{2}$ did not perturb the spectinomycin binding pocket, with a RMSD value of $0.75 \AA$ (Fig. 7d). However, binding of $\mathbf{6}$, the corresponding 6-deoxy analog, shifted $2.47 \AA$ from 2 in the pocket and reduced the calculated $\Delta G$ of binding by $16.0 \mathrm{kcal} \mathrm{mol}^{-1}$ (Table 2). Despite the loss of one hydrogen 

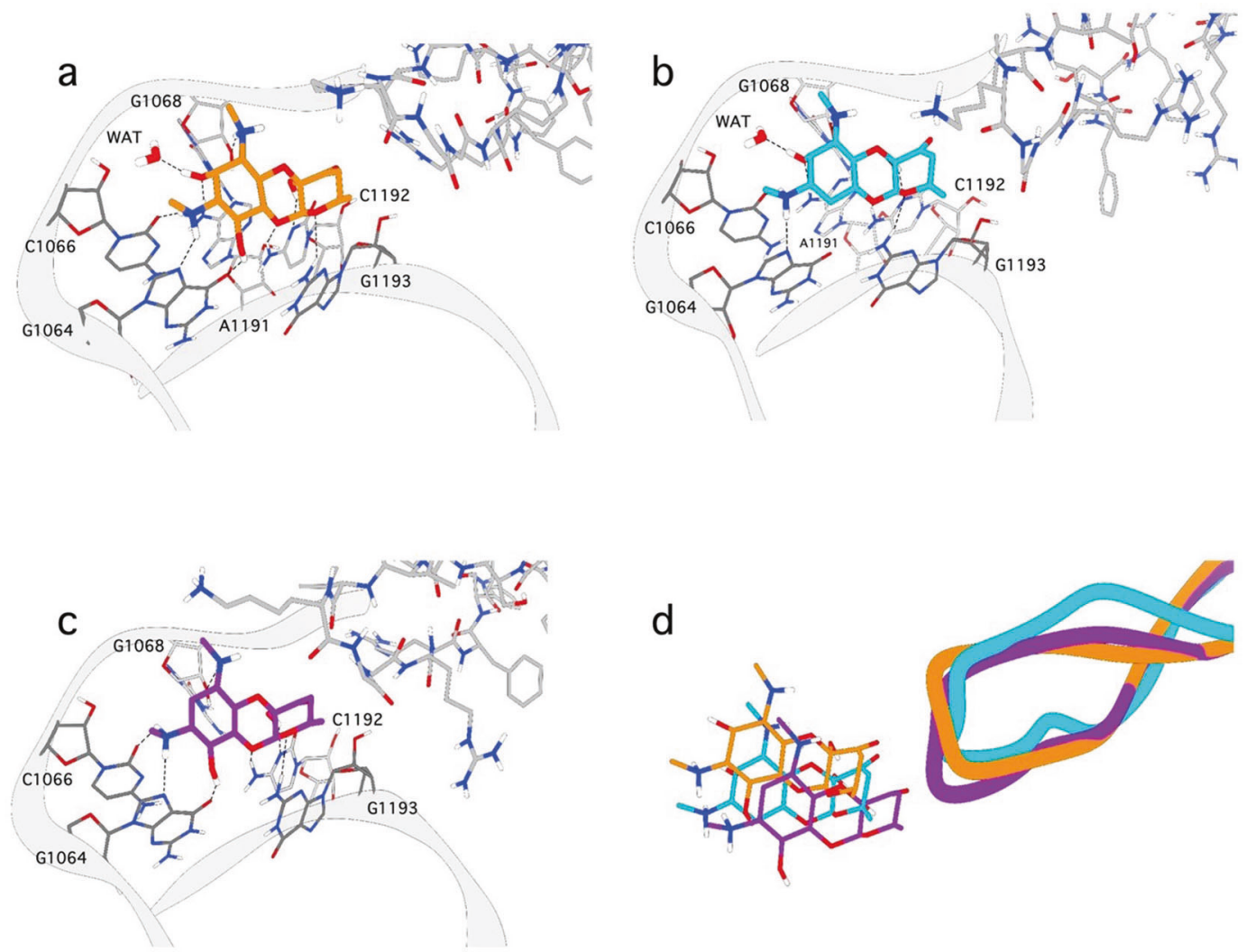

Fig. 6 Snapshot from $20 \mathrm{~ns}$ molecular dynamic simulation of spectinomycin analogs. The binding mode of a spectinomycin, $\mathbf{b ~ 5}$, and $\mathbf{c} 9$ from $20 \mathrm{~ns}$ MD simulations. The protein is shown as a gray ribbon with nucleotides and waters interacting with the ligand are labeled.

bond interaction with G1064, 6 maintains VDW interaction RpsE protein loop (Fig. 7b), improving the $\mathrm{IC}_{50}$ compared to the 6-deoxyspectinomycin analog 5. Additionally, $\mathbf{6}$ gains a hydrogen bonding interaction between G1193 phosphate backbone and the spectinomycin scaffold because of the large shift in the binding pocket (Fig. 7b). In contrast, the 2-deoxyspectinamide analog $\mathbf{1 0}$ remains in the spectinomycin binding pocket with a RMSD value of 1.28 A compared to 2 (Fig. 7d). Losing the A1191 hydrogen bond is alleviated through interactions from the aryl chain to G1193 and VDW interactions with Val56 on the RpsE protein loop (Fig. 7c). Binding of $\mathbf{1 0}$ reduced the $\Delta G$ of binding by $5.3 \mathrm{kcal} \mathrm{mol}^{-1}$ compared to 2 , suggesting the loss of the 2-hydroxy group is more favorable than the 6hydroxy group as observed with deoxyspectinomycin analogs. However, despite loss of the hydroxy groups, both deoxyspectinamide analogs recover binding interactions and rescue activity via additional protein-ligand interactions on the RpsE protein loop.

The calculated $\Delta G$ of binding for the analogs correlates to the measured ribosomal $\mathrm{IC}_{50}$ data; however, the energetic contribution for each nucleotide is unknown from this analysis. Therefore, the free energy decomposition [40] of

The hydrogen bonding interactions are depicted as dashed lines. $\mathbf{d}$ An overlay of spectinomycin (orange), $\mathbf{5}$ (cyan), and $\mathbf{9}$ (purple) from the $20 \mathrm{~ns}$ MD simulations

each nucleotide and amino acid in the binding pocket was compared between the analogs (Fig. 8). From the spectinomycin MD simulation, G1064, C1066, and G1068 have the strongest interaction in the binding pocket, with A1191, C1192, and G1193 being the weakest (Fig. 8 and Table S2). When the 6-hydroxy group is removed, the hydrogen bonding interaction from G1064 is lost and results in a 1.8 $\mathrm{kcal} \mathrm{mol}^{-1}$ decrease in free energy (Fig. 8). The loss of the 6-hydroxy group indirectly effected nucleotide binding interactions with $\mathbf{5}, 0.82 \mathrm{kcal} \mathrm{mol}^{-1}$ loss for $\mathrm{C} 1066$ and $0.45 \mathrm{kcal} \mathrm{mol}^{-1}$ loss for G1068. In contrast, the removal of the 2-hydroxy group did not produce these large changes in the free energy of binding (Fig. 8). Despite the loss of A1191 hydrogen bonding interactions, the $\mathrm{C} 1066$ had the largest loss in free energy of $2.33 \mathrm{kcal} \mathrm{mol}^{-1}$. This trend was observed for the deoxyspectinamide analogs compared to the parent 2 compound. The 6-deoxy 6 analog had a decrease in G1064 free energy by $2.29 \mathrm{kcal} \mathrm{mol}^{-1}$, as the hydrogen bond interaction is lost as observed for $\mathbf{5}$. Additionally, the binding free energy for C1192 decreased, 3.96 $\mathrm{kcal} \mathrm{mol}^{-1}$, which was not observed for $\mathbf{5}$. This change in C1192 binding energy may be a result of the large shift in the binding pocket. The aryl side chain increased binding 

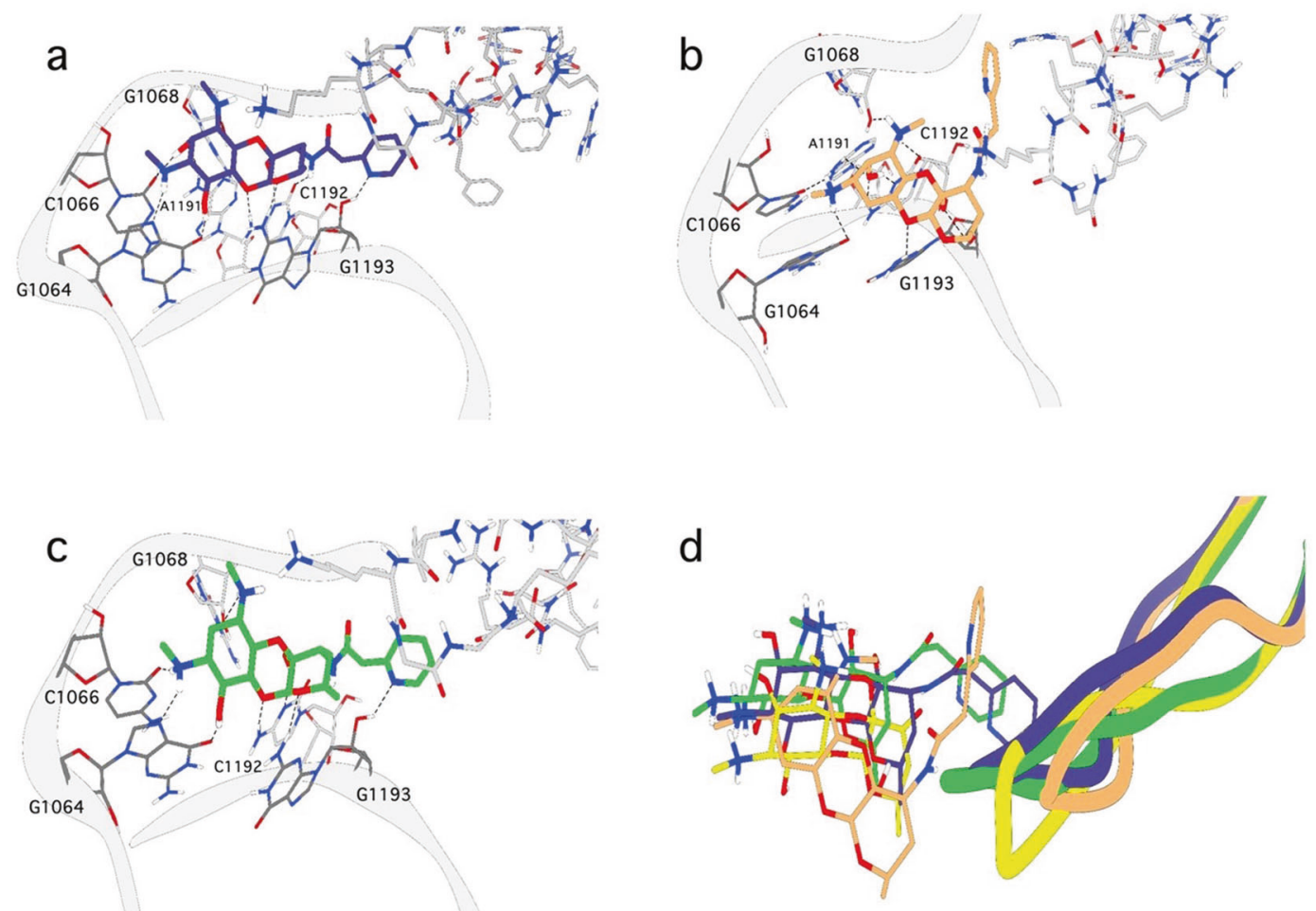

Fig. 7 Modeled binding modes of spectinamide analogs from $20 \mathrm{~ns}$ molecular dynamic simulation in AMBER18. The binding mode of a 2, b 6, and c 10 from $20 \mathrm{~ns}$ MD simulations. The protein is rendered ligand shown as sticks. The dashed lines represent hydrogen bonding interactions. d An overlay of spectinomycin (yellow), 2 (purple), 6 (orange), and $\mathbf{1 0}$ (green) from the $20 \mathrm{~ns}$ MD simulations as a gray ribbon with nucleotides and waters interacting with the

Table 2 Binding free energy onto the Mycobacterial RNA/ RpsE complex determined using the MM/GBSA method in Amber18

\begin{tabular}{lllll}
\hline Compound & $E_{\mathrm{VDW}}{ }^{\mathrm{a}}\left(\mathrm{kcal}^{-1} \mathrm{~mol}^{-1}\right)$ & $E_{\text {nonpolar }}{ }^{\mathrm{a}}\left(\mathrm{kcal}^{-1} \mathrm{~mol}^{-1}\right)$ & $\Delta G_{\text {total }}{ }^{\mathrm{a}}\left(\mathrm{kcal}^{-1} \mathrm{~mol}^{-1}\right)$ & \left.${\text { Ribosomal } \mathrm{IC}_{50}{ }^{\mathrm{b}}(\mu \mathrm{g} \mathrm{ml}}^{-1}\right)$ \\
\hline Spectinomycin & $-38.9 \pm 2.70$ & $-5.41 \pm 0.05$ & $-78.5 \pm 2.32$ & 0.36 \\
$\mathbf{5}$ & $-36.9 \pm 2.60$ & $-5.21 \pm 0.05$ & $-69.9 \pm 2.92$ & $>60$ \\
$\mathbf{9}$ & $-39.3 \pm 2.55$ & $-5.34 \pm 0.05$ & $-72.2 \pm 2.21$ & $>60$ \\
$\mathbf{2}$ & $-57.2 \pm 2.98$ & $-7.29 \pm 0.06$ & $-97.6 \pm 2.78$ & 0.89 \\
$\mathbf{6}$ & $-49.8 \pm 2.76$ & $-6.86 \pm 0.05$ & $-81.6 \pm 2.49$ & 9.50 \\
$\mathbf{1 0}$ & $-56.3 \pm 2.91$ & $-7.34 \pm 0.06$ & $-92.3 \pm 2.27$ & 10.2 \\
\hline
\end{tabular}

${ }^{a}$ Values represent an average over the 1000 MD frames \pm standard deviation

${ }^{\mathrm{b}}$ Tested with $M$. smegmatis interactions with $\mathrm{G} 1193,1.13 \mathrm{kcal} \mathrm{mol}^{-1}$. The 2-deoxy analog 10 maintained similar binding free energies compared to the parent compound $\mathbf{2}$. This is not surprising, as 10 did not perturb the binding pocket, RMSD value of 1.28 $\AA$. The loss of the A1191 binding interaction in the pocket resulted in a $1.16 \mathrm{kcal} \mathrm{mol}^{-1}$ decrease in energy, as well as indirect effect on $\mathrm{C} 1066,1.58 \mathrm{kcal} \mathrm{mol}^{-1}$. The aryl chains in the spectinamide series did increase binding interactions through the RpsE protein loop, as observed in the increase of Val56 free energy (Fig. 8).

From the decomposition of the free energy of binding, loss of the 2-hydroxy group in $\mathbf{9}$ and $\mathbf{1 0}$ did not greatly perturb the binding free energy of the nucleotides in the pocket except for a decrease in C1066 and A1191 (Fig. 8).
However, loss of the 6-hydroxy group in $\mathbf{6}$ greatly impacted the free energy landscape of the binding pocket. Binding free energies decreased for G1064, A1191, and C1192 and increased with G1068 and G1193 (Fig. 8). This increase in energy is a result of shifting the spectinamide out of the pocket to maintain contacts between aryl side chain and the RpsE protein. This compensatory mechanism shown for both 6 and 10 suggests that the aryl side chain on these analogs promote favorable binding interactions, i.e., Val56 (Fig. 8). Structure-based drug discovery of the aryl chain on deoxyspectinamides to increase protein-ligand interactions may be a viable method to overcome the energetic penalties for removing the 2- or 6-hydroxy groups to avoid AME activity. 
Fig. 8 Decomposition of free energy of binding in the spectinomycin binding pocket. The total $\Delta G$ of binding for each nucleotide interacting with spectinomycin 1 (dark red), $\mathbf{5}$ (dark orange), 9 (dark blue), 2 (light red), $\mathbf{6}$ (light orange), and 10 (light blue) in the binding pocket. The $\Delta G$ is an average over the $20 \mathrm{~ns}$ MD ensemble and the error bars represent the standard deviation

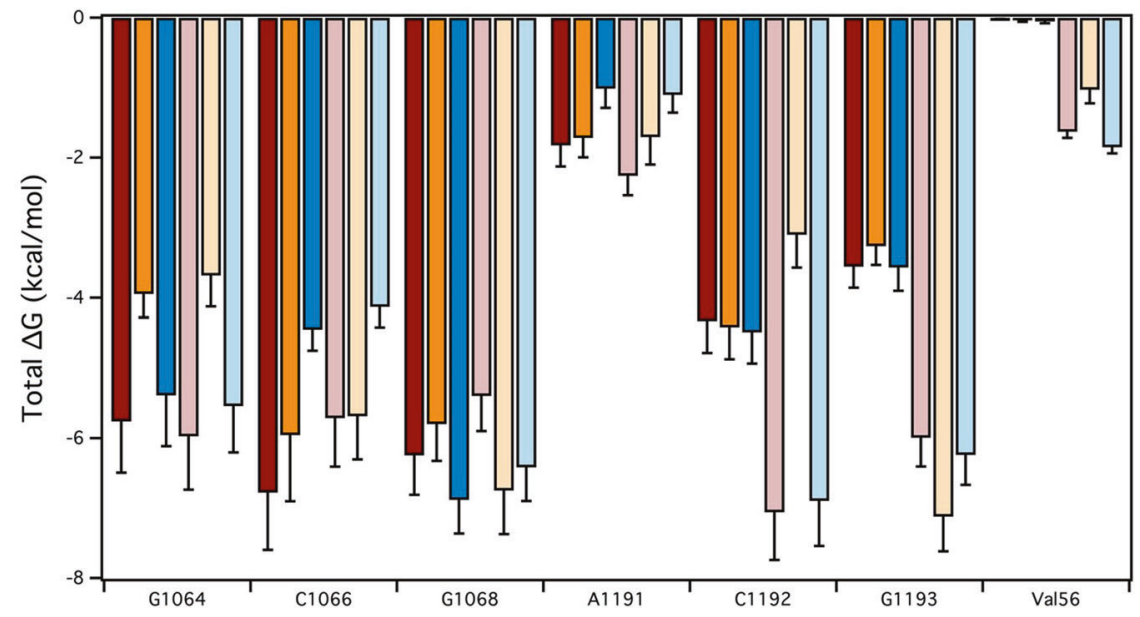

\section{Conclusions}

Aminoglycoside resistance mediated by AME activity remains a major hurdle in the field of antibiotic drug discovery. This study sought to determine how removal or modification of the AME targeted motifs in spectinomycin, and the related spectinamides and amSPCs, affected ribosomal potency, antibacterial activity, and cellular accumulation. We used an efficient method for the deoxygenation of spectinomycin enabling the synthesis of deoxyspectinamides and amSPCs. This method involves formation of imidazolylthiocarbamate and followed by deoxygenation reaction with tributyltin hydride, as used in classical "Barton-McCombie" deoxygenation method. The deoxyspectinomycin analogs had poor antibacterial activity and ribosomal binding affinity, as did the 6-dehydrospectinamide $\mathbf{1 1}$ and the epi-chloro spectinomycin $\mathbf{8}$ also synthesized as comparators. Molecular dynamic simulations followed by energy decomposition of the individual nucleotides involved in spectinomycin binding revealed the 6hydroxy group has a larger effect on binding compared to the 2-hydroxy group consistent with in vitro protein translational inhibition data. These results experimentally validate our modeling approach, which allow for key binding site residues to be targeted in the design of future spectinomycin analogs.

Other important spectinomycin binding/structure-activity information can be gleaned from examining the testing data in this study, including an evaluation of the contribution the aryl side chains make to spectinamide and amSPC binding. In this case, the loss of binding affinity caused by deoxygenation of the spectinomycin ring affinity is demonstrated to be partially rescued by the additional interactions between the RpsE protein and the aryl side chains extending from the deoxyspectinamide and deoxy-amSPC analogs. Deoxygenation decreases the hydrophilicity of the spectinomycins, a goal of our program, as more lipophilic analogs are expected to have higher permeability in mammalian and bacteria cells. However, deoxygenation of the analogs in this study led to only small increases in cellular accumulation and was not found to affect the antimicrobial potency.

This study builds the on the knowledge of the SAR of spectinomycin analogs and is being used to aid the design of next-generation spectinomycins. Analogs that maintain a nonAME modifiable hydrogen bond donor at the 6-position to interact with G1064 in combination with aryl side chains modifications are being explored in subsequent studies. Such analogs may be successful new class of antibiotics targeting the helix-34 ribosomal binding site, overcoming AME resistance, if their overall binding affinities can be increased and their cellular permeability optimized.

Acknowledgements This research was supported by NIH grants (R01AI090810, R01AI136803, and T32AI106700) and ALSAC, St Jude's Children Research Hospital. The content is solely the responsibility of the authors and does not necessarily represent the official views of the National Institutes of Health. ECB and DS thank Tanja Viloria for expert technical assistance.

\section{Compliance with ethical standards}

Conflict of interest The authors declare that they have no coflict of interest.

Publisher's note Springer Nature remains neutral with regard to jurisdictional claims in published maps and institutional affiliations.

Open Access This article is licensed under a Creative Commons Attribution 4.0 International License, which permits use, sharing, adaptation, distribution and reproduction in any medium or format, as long as you give appropriate credit to the original author(s) and the source, provide a link to the Creative Commons license, and indicate if changes were made. The images or other third party material in this article are included in the article's Creative Commons license, unless indicated otherwise in a credit line to the material. If material is not included in the article's Creative Commons license and your intended use is not permitted by statutory regulation or exceeds the permitted use, you will need to obtain permission directly from the copyright holder. To view a copy of this license, visit http://creativecommons. org/licenses/by/4.0/. 


\section{References}

1. Mason DJ, Dietz A, Smith RM. Actinospectacin, a new antibiotic. I. Discovery and biological properties. Antibiot Chemother. 1961;11:118-22.

2. Bergy ME, Eble TE, Herr RR. Actinospectacin, a new antibiotic. IV. Isolation, purification, and chemical properties. Antibiot Chemother. 1961;11:661-4.

3. Carter AP, Clemons WM, Brodersen DE, Morgan-Warren RJ, Wimberly BT, Ramakrishnan V. Functional insights from the structure of the $30 \mathrm{~S}$ ribosomal subunit and its interactions with antibiotics. Nature. 2000;407:340-8.

4. Laird SM, Taylor G. Treatment of gonorrhoea with actinospectacin. Br J Vener Dis. 1962;38:60-3.

5. Fernandes PB, Vojtko CM, Bower RR, Weisz J. Spenolimycin, a new spectinomycin-type antibiotic. III. Biological properties. J Antibiot. 1984;37:1525-7.

6. Balganesh M, Dinesh N, Sharma S, Kuruppath S, Nair AV, Sharma U. Efflux pumps of Mycobacterium tuberculosis play a significant role in antituberculosis activity of potential drug candidates. Antimicrob Agents Chemother. 2012;56:2643-51.

7. Ramon-Garcia S, Martin C, De Rossi E, Ainsa JA. Contribution of the Rv2333c efflux pump (the Stp protein) from Mycobacterium tuberculosis to intrinsic antibiotic resistance in Mycobacterium bovis BCG. J Antimicrob Chemother. 2007;59:544-7.

8. Galimand M, Gerbaud G, Courvalin P. Spectinomycin Resistance in Neisseria spp. Due to mutations in 16S rRNA. Antimicrob Agents Chemother. 2000;44:1365-6.

9. Sandvang D. Novel streptomycin and spectinomycin resistance gene as a gene cassette within a class 1 integron isolated from Escherichia coli. Antimicrob Agents Chemother. 1999;43:3036-8.

10. Lee RE, Hurdle JG, Liu J, Bruhn DF, Matt T, Scherman MS, et al. Spectinamides: a new class of semisynthetic antituberculosis agents that overcome native drug efflux. Nat Med. 2014;20:152-8.

11. Bruhn DF, Waidyarachchi SL, Madhura DB, Shcherbakov D, Zheng Z, Liu J, et al. Aminomethyl spectinomycins as therapeutics for drug-resistant respiratory tract and sexually transmitted bacterial infections. Sci Transl Med. 2015;7:288ra275.

12. Iverson A, Meyer CJ, Vogel P, Waidyarachchi S, Das N, Bruhn DF, et al. Efficacy of aminomethyl spectinomycins against complex upper respiratory tract bacterial infections. Antimicrob Agents Chemother. 2019;63:e02096-18.

13. Scarff JM, Waidyarachchi SL, Meyer CJ, Lane DJ, Chai W, Lemmon MM, et al. Aminomethyl spectinomycins: a novel antibacterial chemotype for biothreat pathogens. J Antibiot. 2019;72: 693-701.

14. Butler MM, Waidyarachchi SL, Connolly KL, Jerse AE, Chai W, Lee RE, et al. Aminomethyl spectinomycins as therapeutics for drug-resistant gonorrhea and chlamydia coinfections. Antimicrob Agents Chemother. 2018;62:e0325-18.

15. Ramirez MS, Tolmasky ME. Aminoglycoside modifying enzymes. Drug Resist Updat. 2010;13:151-71.

16. Suter TM, Viswanathan VK, Cianciotto NP. Isolation of a gene encoding a novel spectinomycin phosphotransferase from Legionella pneumophila. Antimicrob Agents Chemother. 1997;41:1385-8.

17. Zárate SG, De la Cruz Claure ML, Benito-Arenas R, Revuelta J, Santana AG, Bastida A. Overcoming aminoglycoside enzymatic resistance: design of novel antibiotics and inhibitors. Molecules. 2018;23:284.

18. Kanchugal PS, Selmer M. Structural recognition of spectinomycin by resistance enzyme ANT(9) from Enterococcus faecalis. Antimicrob Agents Chemother. 2020;64:e00371-20.

19. Stern AL, Van der Verren SE, Kanchugal PS, Nasvall J, Gutierrez-de-Teran H, Selmer M. Structural mechanism of AadA, a dual-specificity aminoglycoside adenylyltransferase from Salmonella enterica. J Biol Chem. 2018;293:11481-90.

20. Foley L, Lin JT, Weigele M. Spectinomycin chemistry. II.) 9Deoxy-4(R)-dihydrospectinomycin and 9-deoxyspectinomycin. J Antibiot. 1978;31:979-84.

21. Foley L, Lin JT, Weigele M. Preparation of 7-deoxyspectinomycin and 7-deoxy-8-epi-4(R)-dihydrospectinomycin. J Antibiot. 1979;32: 418-9.

22. Rosenbrook W, Carney RE. Spectinomycin modification. I. 7-Epi9-deoxy-4(R)-dihydrospectinomycin. J Antibiot. 1975;28:953-9.

23. Barton DHR, McCombie SW. A new method for the deoxygenation of secondary alcohols. J Chem Soc. 1975:1574-85. https://doi.org/10.1039/P19750001574.

24. Carney RE, Rosenbrook W. Spectinomycin modification. III Chloro-deoxy analogs. J Antibiot. 1977;30:960-4.

25. Liu J, Bruhn DF, Lee RB, Zheng Z, Janusic T, Scherbakov D, et al. Structure-activity relationships of spectinamide antituberculosis agents: a dissection of ribosomal inhibition and native efflux avoidance contributions. ACS Infect Dis. 2017;3:72-88.

26. Borovinskaya MA, Pai RD, Zhang W, Schuwirth BS, Holton JM, Hirokawa G, et al. Structural basis for aminoglycoside inhibition of bacterial ribosome recycling. Nat Struct Mol Biol. 2007;14:727-32.

27. Jacobson MP, Friesner RA, Xiang Z, Honig B. On the role of the crystal environment in determining protein side-chain conformations. J Mol Biol. 2002;320:597-608.

28. Jacobson MP, Pincus DL, Rapp CS, Day TJ, Honig B, Shaw DE, et al. A hierarchical approach to all-atom protein loop prediction. Proteins. 2004;55:351-67.

29. Pontius J, Richelle J, Wodak SJ. Deviations from standard atomic volumes as a quality measure for protein crystal structures. J Mol Biol. 1996;264:121-36.

30. Harder E, Damm W, Maple J, Wu C, Reboul M, Xiang JY, et al. OPLS3: a force field providing broad coverage of drug-like small molecules and proteins. J Chem Theory Comput. 2016;12:281-96.

31. Sastry GM, Adzhigirey M, Day T, Annabhimoju R, Sherman W. Protein and ligand preparation: parameters, protocols, and influence on virtual screening enrichments. J Comput Aided Mol Des. 2013;27:221-34.

32. Greenwood JR, Calkins D, Sullivan AP, Shelley JC. Towards the comprehensive, rapid, and accurate prediction of the favorable tautomeric states of drug-like molecules in aqueous solution. $\mathrm{J}$ Comput Aided Mol Des. 2010;24:591-604.

33. Friesner RA, Banks JL, Murphy RB, Halgren TA, Klicic JJ, Mainz DT, et al. Glide: a new approach for rapid, accurate docking and scoring. 1. method and assessment of docking accuracy. J Medicinal Chem. 2004;47:1739-49.

34. Friesner RA, Murphy RB, Repasky MP, Frye LL, Greenwood JR, Halgren TA, et al. Extra precision glide: docking and scoring incorporating a model of hydrophobic enclosure for protein -ligand complexes. J Med Chem. 2006;49:6177-96.

35. Halgren TA, Murphy RB, Friesner RA, Beard HS, Frye LL, Pollard WT, et al. Glide: a new approach for rapid, accurate docking and scoring. 2. Enrichment factors in database screening. J Med Chem. 2004;47:1750-9.

36. Case DA, Ben-Shalom IY, Brozell SR, Cerutti DS, Cheatham TE, III, Cruzeiro VWD, et al. AMBER. San Francisco: University of California; 2018.

37. Aytenfisu AH, Spasic A, Grossfield A, Stern HA, Mathews DH. Revised RNA dihedral parameters for the amber force field improve RNA molecular dynamics. J Chem Theory Comput. 2017;13:900-15.

38. Wang J, Wolf RM, Caldwell JW, Kollman PA, Case DA. Development and testing of a general Amber force field. J Comput Chem. 2004;25:1157-74.

39. Maier JA, Martinez C, Kasavajhala K, Wickstrom L, Hauser KE, Simmerling C. ff14SB: improving the accuracy of protein side 
chain and backbone parameters from ff99SB. J Chem Theory Comput. 2015;11:3696-713.

40. Miller BR, McGee TD, Swails JM, Homeyer N, Gohlke H, Roitberg AE. MMPBSA.py: an efficient program for end-state free energy calculations. J Chem Theory Comput. 2012;8:3314-21.

41. Weinstein MP. Performance standards for antimicrobial susceptibility testing. 30th ed. Clinical and Laboratory Standards Institute; 2020. p. 332

42. Richter MF, Drown BS, Riley AP, Garcia A, Shirai T, Svec RL, et al. Predictive compound accumulation rules yield a broadspectrum antibiotic. Nature. 2017;545:299-304.

43. Wallace MJ, Dharuman S, Fernando DM, Reeve SM, Gee CT, Yao J, et al. Discovery and characterization of the antimetabolite action of thioacetamide-linked 1,2,3-triazoles as disruptors of cysteine biosynthesis in gram-negative bacteria. ACS Infect Dis. 2020;6:467-78.

44. Rosenbrook W, Carney RE, Egan RS, Stanaszek RS, Cirovic M, Nishinaga T, et al. Spectinomycin modification. II. 7-Episepctinomycin. J Antibiot. 1975;28:960-4.
45. Maier R, Woitun E, Reuter A, Reuter W, Wetzel B. Modification of spectinomycin 1. Synthesis of 4-aminospectinomycins. J Antibiot. 1981;34:16-21.

46. Woitun E, Maier R, Wetzel B, Reuter W, Lechner U. Modification of spectinomycin 2. Derivatives of 4-dihydro-4-deoxy-4(R)-aminospectinomycin. J Antibiot. 1981;34:22-7.

47. Maier R, Woitun E, Reuter A, Reuter W, Wetzel B. Modification of spectinomycin. 1. Synthesis of 4-aminospectinomycins. J Antibiot. 1981;34:16-21.

48. Hou T, Wang J, Li Y, Wang W. Assessing the performance of the MM/PBSA and MM/GBSA methods. 1. The accuracy of binding free energy calculations based on molecular dynamics simulations. J Chem Inf Model. 2011;51:69-82.

49. Notredame C, Higgins DG, Heringa J. T-coffee: a novel method for fast and accurate multiple sequence alignment. J Mol Biol. 2000;302:205-17.

50. Robert X, Gouet P. Deciphering key features in protein structures with the new ENDscript server. Nucleic Acids Res. 2014;42: W320-4. 